\title{
CARDIAC GLYCOSIDE RECEPTORS IN CULTURED HEART CELLS-II
}

\author{
CHARACTERIZATION OF A HIGH AFFINITY AND A LOW AFFINITY \\ BINDING SITE IN HEART MUSCLE CELLS FROM NEONATAL RATS*
}

\author{
KARL WERDAN, BERNHARD WAGENKNECHT, BERNHARD ZWISSLER, LiNDSAy BROWN, \\ WOLFGANG KRAWIETZ and ERLAND ERDMANN \\ Medizinische Klinik I der Universität München, Klinikum Grosshadern, D-8000 München 70, \\ Federal Republic of Germany
}

(Received 27 July 1983; accepted 13 December 1983)

\begin{abstract}
The binding of $\left[{ }^{3} \mathrm{H}\right]$ ouabain has been studied in $\left(\mathrm{Na}^{+}+\mathrm{K}^{+}\right)$-ATPase enriched cardiac cell membranes, as well as in cardiac muscle and non-muscle cells in culture-all obtained from hearts of neonatal rats. The binding has been correlated with ouabain-induced inhibition of $\left(\mathrm{Na}^{+}+\mathrm{K}^{+}\right)$-ATPase (cardiac cell membranes) and the inhibition of active $\left({ }^{86} \mathrm{Rb}^{+}+\mathrm{K}^{+}\right)$-influx (cardiac muscle and nonmuscle cells in culture). Furthermore, the effect of ouabain on the amplitude of cell-wall motion and contraction velocity has been studied in electrically driven cardiac muscle cells.

In muscle and non-muscle cells, two classes of ouabain binding sites have been identified. In rat heart muscle cells, the high affinity binding site has a dissociation constant $\left(K_{D}\right)$ of $3.2 \times 10^{-8} \mathrm{M}$ and a binding capacity $(B)$ of $0.2 \mathrm{pmole} / \mathrm{mg}$ protein $(80,000 \mathrm{sites} / \mathrm{cell})$; the values for the low affinity binding site are: $K_{D}=7.1 \times 10^{-6} \mathrm{M} ; B=2.6 \mathrm{pmole} / \mathrm{mg}$ protein $\left(10^{6} \mathrm{sites} / \mathrm{cell}\right)$. The binding to both types of binding sites is depressed by $\mathrm{K}^{+}$and abolished after heat denaturation of the cells. The kinetics of $\left[{ }^{3} \mathrm{H}\right]$ ouabain binding to rat heart muscle cells (association and dissociation rate constants, $\mathrm{K}^{+}$- and temperaturedependence of association and dissociation processes) have been characterized.

In rat heart muscle and non-muscle cells, the binding of $\left[{ }^{3} \mathrm{H}\right]$ ouabain to the low affinity site results in inhibition of the $\left({ }^{86} \mathrm{Rb}^{+}+\mathrm{K}^{+}\right)$-influx $\left(\mathrm{EC}_{50}=1.3\right.$ and $1.5 \times 10^{-5} \mathrm{M}$ ouabain), a decrease in cell- $\mathrm{K}^{+}$ $\left(\mathrm{EC}_{50}=1.9\right.$ and $\left.1.4 \times 10^{-5} \mathrm{M}\right)$ and an increase in cell- $\mathrm{Na}^{+}\left(10^{-5}-10^{-4} \mathrm{M}\right)$. The ouabain-induced positive inotropic effect (increase in amplitude of cell-wall motion, increase in contraction velocity) in cardiac muscle cells is observed only at ouabain concentrations $\geqslant 5 \times 10^{-6} \mathrm{M}$, and it is therefore probably attributed to occupation of the low affinity binding site. Coupling of occupation of the low affinity site by ouabain with drug-induced inhibition of the sodium pump and with drug-induced positive inotropic action is further substantiated by kinetic measurements. In contrast, occupation of the high affinity binding site does not produce any measurable inhibition of the sodium pump activity or positive inotropy.

In agreement with the findings in intact cells, two classes of ouabain binding sites $\left(K_{D}=2.2 \times 10^{-8}\right.$ and $\left.1.3 \times 10^{-4} \mathrm{M}\right)$ have been characterized in $\left(\mathrm{Na}^{+}+\mathrm{K}^{+}\right)$-ATPase enriched cardiac cell membranes from neonatal rats; only the binding of ouabain to the low affinity binding site produces a measurable inhibition of $\left(\mathrm{Na}^{+}+\mathrm{K}^{+}\right)$-ATPase activity $\left(\mathrm{EC}_{50}=4.8 \times 10^{-5} \mathrm{M}\right.$ ouabain).

Our results support the finding of different types of ouabain binding sites in rat heart. The nature of the high affinity/low capacity ouabain binding site remains to be elucidated.
\end{abstract}

Despite the long-standing use of cardiac glycosides in the treatment of heart failure, this mechanism of positive inotropic action is still a matter of controversy [2]. Recently, glycoside-induced inhibition of the sodium pump as the exclusive cause of positive inotropy has again been questioned by experimental evidence for two classes of cardiac glycoside receptors in rat heart: in isolated cell membranes from rat heart, two classes of binding sites for $\left[{ }^{3} \mathrm{H}\right]$ ouabain have been demonstrated $\left(K_{D_{1}}=1.05 \times 10^{-7} \mathrm{M}\right.$, $\left.K_{D_{2}}=2.8 \times 10^{-5} \mathrm{M}\right)$, only the low affinity, high capacity site being linked to the inhibition of $\left(\mathrm{Na}^{+}+\mathrm{K}^{+}\right)$-ATPase [3]. Accordingly, in rat ventricular strips, the positive inotropic action of ouabain is linked to a class of high affinity binding sites $\left(K_{D}=3 \times 10^{-7} \mathrm{M}\right)$, while inhibition of active

- Part of these results were presented at the Annual Meeting of the German Society for Cell Biology, Munich, Federal Republic of Germany, March 1982 [1]. $\left({ }^{86} \mathrm{Rb}^{+}+\mathrm{K}^{+}\right)$-uptake $\left(\mathrm{EC}_{50}=3 \times 10^{-5} \mathrm{M}\right)$ is independent of binding of ouabain to this high affinity binding site [3].

Subsequently, the existence of more than one mode of positive inotropic action of cardiac glycosides in rat heart has been claimed by further experimental evidence; confirmation of the existence of two classes of ouabain binding sites $\left(K_{D_{1}}=\right.$ $\left.1.9 \times 10^{-7} \mathrm{M} ; K_{D_{2}}=1.4 \times 10^{-5} \mathrm{M}\right)$ in membrane preparations from rat atria and ventricles [4]; a 'high dose' and a 'low dose' positive inotropic effect of ouabain in rat atria and ventricles [4-7], only the 'low dose' component being linked to changes in ion gradients [4]. Furthermore, two or three forms of $\left(\mathrm{Na}^{+}+\mathrm{K}^{+}\right)$-ATPase seem to exist in rat heart $[8,9]$. Thus, experimental evidence suggests that at least part of the positive inotropic action of cardiac glycosides in rat heart is mediated by a mechanism independent of cardiac glycoside-induced inhibition of the sodium pump. 
Despite this evidence of the existence of two discernible classes of cardiac glycoside receptors in membrane preparations and intact tissue of rat heart, only one class of saturable binding sites for ouabain has been described in cultured heart muscle cells from neonatal rats: McCall [10] has characterized a high affinity binding site for ouabain $\left(K_{D}=\right.$ $\left.2 \times 10^{-7} \mathrm{M}\right)$, with $\mathrm{ca} 1.6 \times 10^{6}$ binding sites/cell. Heller and coworkers $[11,12]$ also describe a saturable, $K^{+}$-sensitive, high affinity $\left(K_{D}=8.9 \times\right.$ $10^{-8} \mathrm{M}$ ) binding site for ouabain. In addition, nonsaturable, $\mathrm{K}^{+}$-insensitive ouabain binding has been found by them. None of the groups, however, have correlated ouabain binding with sodium pump inhibition and positive inotropic action in these cells. We have therefore measured the binding of $\left[{ }^{3} \mathrm{H}\right]$ ouabain to cultured muscle cells from neonatal rats, and have correlated the binding with the inhibition of active $\left({ }^{86} \mathrm{Rb}^{+}+\mathrm{K}^{+}\right)$-transport, as well as with positive inotropic action of ouabain in these cells. Our data support the existence of two saturable classes of ouabain binding sites in rat heart.

\section{MATERIALS AND METHODS}

Materials. Chemicals were purchased from NEN Chemicals (Dreieich, F.R.G.) ${ }^{22} \mathrm{NaCl}$, carrier-free; ${ }^{86} \mathrm{RbCl}, \quad 0.9-4.6 \mathrm{mCi} / \mathrm{mg} ;\left[{ }^{3} \mathrm{H}\right]$ ouabain, $14-20 \mathrm{Ci} /$ mmole); Serva Biochemica (Heidelberg, F.R.G.) (trypsin 1:250, No. 37290); and Biochrom (Berlin, F.R.G.) (collagenase 'Worthington', 125-250 U/mg, CLS II; fetal calf serum; horse serum; CMRL 1415 ATM medium). All other chemicals were of analytical grade and were purchased from Merck (Darmstadt, F.R.G.) and Boehringer-Mannheim (Mannheim, F.R.G.).

Preparation of $\left(\mathrm{Na}^{+}+\mathrm{K}^{+}\right)$-ATPase enriched cardiac cell membranes obtained from neonatal rats. The hearts of 200 neonatal Wistar rats (1-3-days-old; net wt $6.6 \mathrm{~g}$ ) were quickly excised after cervical dislocation. The hearts were homogenized in a PotterElvejhem homogenizer with $60 \mathrm{ml}$ of $0.25 \mathrm{M}$ sucrose and $1 \mathrm{mM}$ EDTA, adjusted to $\mathrm{pH} 7.25$ with imidazole. To this homogenate, $5 \mathrm{ml}$ of a $5 \%$ solution of sodium deoxycholate was added dropwise. After the homogenate was stirred for $20 \mathrm{~min}$ at $0^{\circ}$, it was centrifuged for $30 \mathrm{~min}$ at $25,000 \mathrm{rpm}$ (Beckman L 550 , $\mathrm{Ti} 35$ rotor).

The supernatant was diluted with an equal volume of $1 \mathrm{mM}$ EDTA, $\mathrm{pH} 7.25$, and centrifuged at $44,000 \mathrm{rpm}$ for $45 \mathrm{~min}$ ( $\mathrm{Ti} 60$ rotor). The pellet was suspended in $18 \mathrm{ml}$ of $1 \mathrm{mM}$ EDTA, pH 7.25, and kept frozen at $-20^{\circ}$ until use. Before use, the suspension was thawed at room temperature and homogenized in a Potter-Elvejhem homogenizer.

$\left(\mathrm{Na}^{+}+\mathrm{K}^{+}\right)$-ATPase activity was measured by the coupled optical assay procedure [13]. Total activity was $c a 0.12 \mu \mathrm{mole}$ ATP hydrolysed/min per mg protein at $37^{\circ}$. About $63 \%$ of the activity was inhibited by $10^{-3} \mathrm{M}$ ouabain. Protein was determined by the procedure of Lowry et al. [14], using bovine serum albumin as standard.

Cell culture techniques. Muscle and non-muscle cells from hearts of neonatal Wistar rats (1-3-daysold) were prepared under sterile conditions and separately cultured as described recently $[15,16]$. In brief, this consisted of: disaggregation of $50-200$ hearts by repeated incubation ( 10 min periods at $37^{\circ}$ ) in trypsin $(0.12 \%)$-collagenase $(0.03 \%)$-salt solution $\left(\mathrm{Ca}^{2+}, \mathrm{Mg}^{2+}\right.$-free); separate cultivation of muscle cells (seeding density $\sim 10^{5}$ cells $/ \mathrm{cm}^{2}$ ) and non-muscle cells in $25 \mathrm{~cm}^{2}$ plastic flasks (Nunclon Plastics, DK-Roskilde, Denmark) at $37^{\circ}$ after application of the differential attachment technique [17], in growth medium (CMRL 1415 ATM, bicarbonatefree, supplemented with $10 \%$ fetal calf serum and $0.05 \mathrm{mg} / \mathrm{ml}$ gentamycin, $\mathrm{pH} 7.40$ ). The medium for cultivation of the cardiac muscle cells was additionally supplemented with $10 \%$ horse serum. Experiments were carried out with muscle cells after 2 3 days in culture, with non-muscle cells after one subcultivation [splitting ratio $1: 2$, detachment of the cells by $0.25 \%$ trypsin $+0.02 \%$ EDTA in $\mathrm{Ca}^{2+}$, $\mathrm{Mg}^{2+}$-free solution (Biochrom, Berlin)]. At that time, muscle ce!ls had formed a synchronously beating monolayer; non-muscle cells were confluent.

The term 'non-muscle cells' refers to heart cells in culture, lacking sarcomeres, and mainly consisting of fibroblasts and endothelial cells [18]. In contrast to cardiac muscle cells, they possess a high proliferation capacity and attach rapidly to the culture flask after seeding [17].

Measurement of $\left({ }^{86} \mathrm{Rb}^{+}+\mathrm{K}^{+}\right)$-influx, $\left[{ }^{3} \mathrm{H}\right]$ ouabain binding and cellular contents of $\mathrm{Na}^{+}$and $\mathrm{K}^{+}$in rat heart cells in culture. Unless otherwise stated, measurements were carried out at $37^{\circ}$ with cells $(0.2-$ $2.0 \mathrm{mg}$ protein/flask) in $25 \mathrm{~cm}^{2}$ plastic flasks in serumsupplemented $(2.5 \%$ fetal calf serum, $2.5 \%$ horse serum), HEPES-buffered (20 mM, pH 7.40) CMRL 1415 ATM medium with a lowered $\mathrm{K}^{+}$concentration $(0.75 \mathrm{mM})$. This is designated the 'standard medium'.

For measurements of $\left({ }^{86} \mathrm{Rb}^{+}+\mathrm{K}^{+}\right)$-uptake, cells were incubated for 10 min with ${ }^{86} \mathrm{Rb}^{+}$in tracer amounts $[15,16]$, the $\mathrm{K}^{+}$concentration in the medium normally being $0.75 \mathrm{mM}$. Uptake of ${ }^{86} \mathrm{Rb}^{+}$ was linear at least for $10 \mathrm{~min}$ [16]. In the experiment shown in Fig. 7, the rates of $\left({ }^{86} \mathrm{Rb}^{+}+\mathrm{K}^{+}\right)$-uptake changed within minutes. Therefore, it was necessary in this experiment to measure the rates of $\left({ }^{86} \mathrm{Rb}^{+}+\mathrm{K}^{+}\right)$-uptake in shorter time intervals (1 min) than usual. Washing procedures, lysis of the cells, determination of cellular radioactivity and measurement of cell protein according to the method of Lowry et al. [14] have been described in detail elsewhere [15]. Measurement of $\left[{ }^{3} \mathrm{H}\right]$ ouabain bound to the cells was carried out in a similar manner, normally after an incubation period of $4 \mathrm{hr}$ (see also legends to figures and tables). Cellular $\mathrm{K}^{+}$contents were measured by flame photometry; the exchangeable pool of intracellular $\mathrm{Na}^{+}$was obtained by measurement of cellular $\mathrm{Na}^{+}$tracer under equilibrium conditions [16]

Determination of cell number/mg protein for rat heart muscle cells in culture. The ratio of cell number/ $\mathrm{mg}$ protein was determined after cultivation of the cells for 2-3 days as described above. Thereafter, cells were detached from the ground by trypsinEDTA solution (see above), and cell number was counted under a phase contrast microscope, while protein was determined according to the method of Lowry et al. [14]. In six experiments, a mean ratio of 
$(1.5 \pm 0.2) \times 10^{6}$ cells $/ \mathrm{mg}$ protein $($ mean \pm S.E.M.) was found.

Details of further methods used [simultaneous measurement of $\left[{ }^{3} \mathrm{H}\right]$ ouabain binding and $\left(\mathrm{Na}^{+}+\mathrm{K}^{+}\right)$-ATPase activity in cardiac cell membranes from neonatal rats; monitoring of beating of electrically driven rat heart muscle cells in culture] are given in the legends of Fig. 1 and 9, respectively.

The data presented in this report are mean values from closely correlating duplicates or triplicates. Unless otherwise stated, all experiments were carried out at least three times. Representative S.D. values are given in some of the experiments.

\section{RESULTS}

$\left[{ }^{3} \mathrm{H}\right]$ Ouabain binding and $\left(\mathrm{Na}^{+}+\mathrm{K}^{+}\right)$-ATPase inhibition by ouabain in cardiac cell membranes from neonatal rats

For reason of comparison, $\left[{ }^{3} \mathrm{H}\right]$ ouabain binding and $\left(\mathrm{Na}^{+}+\mathrm{K}^{+}\right)$-ATPase inhibition by ouabain were not only studied in intact myocardial cells in culture (see following sections), but also in $\left(\mathrm{Na}^{+}+\mathrm{K}^{+}\right)$ATPase enriched cardiac membranes obtained from hearts of neonatal rats, the same source being used as for the preparation of cultured heart cells.

For measurement of $\left[{ }^{3} \mathrm{H}\right]$ ouabain binding and enzyme inhibition under identical conditions, cardiac membranes were incubated with $\left[{ }^{3} \mathrm{H}\right]$ ouabain $\left(5 \times 10^{-9}-10^{-3} \mathrm{M}\right)$. After an incubation period of $60 \mathrm{~min}$-representing equilibrium conditions for binding (results not shown)- $\left[{ }^{3} \mathrm{H}\right]$ ouabain binding was determined by a rapid filtration method $(\mathrm{O}-\mathrm{O}$, Fig. 1) and $\left(\mathrm{Na}^{+}+\mathrm{K}^{+}\right)$-ATPase activity was measured by the coupled optical assay (- Fig. 1) Half-maximal inhibition of enzyme activity occurred at $4.8 \times 10^{-5} \mathrm{M}$ ouabain, which is close to that reported for ouabain-induced $\left(\mathrm{Na}^{+}+\mathrm{K}^{+}\right)$-ATPase inhibition in cardiac membranes from adult rats $\left(4 \times 10^{-5} \mathrm{M}[3]\right)$ and that for digoxin-induced inhibition in neonatal rats $\left(\mathrm{EC}_{50}=2.1 \times 10^{-6} \mathrm{M}\right.$; [19]). Plotting the binding data of Fig. 1 according to Scatchard [20] yielded a curved line (inset of Fig. 1). Negative cooperativity of ouabain binding was excluded by measurement of $\left[{ }^{3} \mathrm{H}\right]$ ouabain dissociation in the presence and absence of excess unlabelled ouabain (results not shown), according to the proposal of De Meyts and Roth [21]. Therefore, the curved Scatchard plot is indicative of the existence of more than one class of binding sites for ouabain. Applying the method of Weidemann et al. [22]-assuming the existence of two classes of binding sites-gave a high affinity, low capacity site $\left(K_{D}=2.2 \times 10^{-8} \mathrm{M} ; \mathrm{ca}\right.$ $1 \%$ of total binding sites) and a low affinity, high capacity site $\left(K_{D}=1.3 \times 10^{-4} \mathrm{M}\right)$. Again, the finding of two classes of ouabain binding sites in cardiac

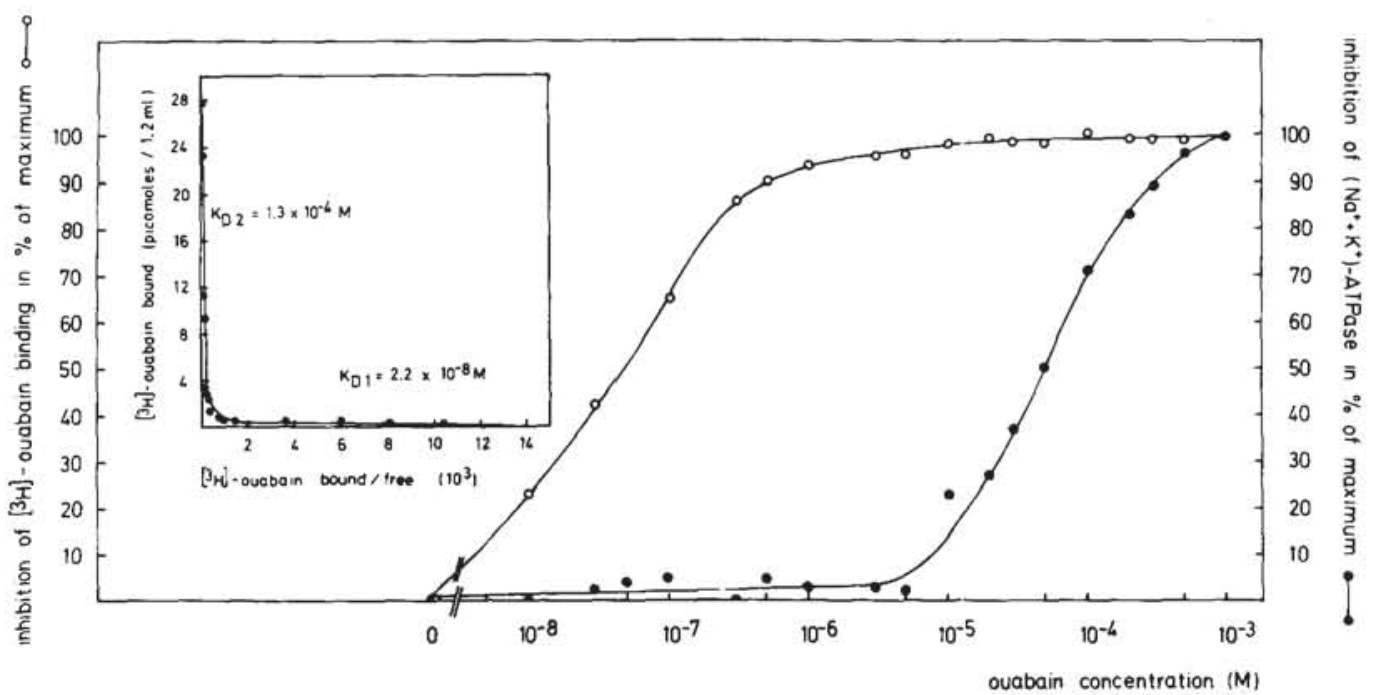

Fig. 1. Specific $\left[{ }^{3} \mathrm{H}\right]$ ouabain binding to and ouabain-induced inhibition of $\left(\mathrm{Na}^{+}+\mathrm{K}^{+}\right)$-ATPase in cardiac cell membranes from neonatal rats. Cardiac cell membranes $\left[0.82 \mathrm{mg}\right.$ protein; $\left(\mathrm{Na}^{+}+\mathrm{K}^{+}\right)$- $\mathrm{ATPase}$ activity $0.07 \mu$ mole ATP hydrolysed/min per mg protein at $37^{\circ}$ ] were incubated at $37^{\circ}$ in $3 \mathrm{mM} \mathrm{MgCl}_{2}$, $3 \mathrm{mM}$ imidazole $/ \mathrm{PO}_{4}, 50 \mathrm{mM}$ imidazole- $\mathrm{HCl}$ buffer, $\mathrm{pH} 7.25,5 \times 10^{-9} \mathrm{M}\left[{ }^{3} \mathrm{H}\right]$ ouabain and increasing amounts of unlabelled ouabain $\left(10^{-8}-10^{-3} \mathrm{M}\right)$, total volume $2.0 \mathrm{ml}$. After $60 \mathrm{~min}$ (time of equilibrium for ouabain binding to these membranes), $0.8 \mathrm{ml}$ of this incubation mixture was removed for the determination of $\left(\mathrm{Na}^{+}+\mathrm{K}^{-}\right)$-ATPase activity by coupled optical assay [13] and the remaining $1.2 \mathrm{ml}$ was used for the determination of $\left[{ }^{3} \mathrm{H}\right]$ ouabain binding by rapid filtration through Whatman $\mathrm{GF} / \mathrm{C}$ glass fibre filters [3]. Unspecific ouabain binding (in the presence of $10^{-3} \mathrm{M}$ ouabain) was less than $5 \%$ of the total radioactivity bound to the membranes and was subtracted. About $63 \%$ of ATPase activity was inhibited by $10^{-3} \mathrm{M}$ ouabain. This portion was assumed to represent $\left(\mathrm{Na}^{+}+\mathrm{K}^{+}\right)$-ATPase enzyme activity. For measurement of $\left(\mathrm{Na}^{+}+\mathrm{K}^{+}\right)$-ATPase activity by the coupled optical assay, each cuvette contained the same ouabain concentration as in the incubation medium. $\left(\mathrm{Na}^{+}+\mathrm{K}^{+}\right)$-ATPase activity was inhibited by $50 \%$ at a concentration of $4.8 \times 10^{-5} \mathrm{M}$ ouabain..

Inset to Fig. 1: Scatchard plot analysis of $\left[{ }^{3} \mathrm{H}\right]$ ouabain binding shown in Fig. 1. Analysis of the Scatchard plot [20] by the method of Weidemann et al. [22] for two binding sites gave a high affinity/ low capacity binding site $\left(K_{D}=2.2 \times 10^{-8} \mathrm{M}\right.$; $c a 1 \%$ of total binding sites) and a low affinity/high capacity site $\left(K_{D}=1.3 \times 10^{-4} \mathrm{M}\right)$. 
membranes from neonatal rats corresponds with the presence of two classes of ouabain binding sites in cardiac cell membranes from adult rats [3].

Specific $\left[{ }^{3} \mathrm{H}\right]$ ouabain binding to cultured cardiac muscle and non-muscle cells from neonatal rats

For measurement of cellular $\left[{ }^{3} \mathrm{H}\right]$ ouabain binding, monolayers of rat heart muscle cells were incubated with $6 \times 10^{-8} \mathrm{M}\left[{ }^{3} \mathrm{H}\right]$ ouabain at $37^{\circ}$. After different incubation periods, cell-bound $\left[{ }^{3} \mathrm{H}\right]$ ouabain was determined, and the values obtained were plotted vs incubation time (- Fig. 2). Initial, rapid binding was almost completed within $30 \mathrm{~min}$, being superimposed by a slower, nearly linear binding process over the whole incubation period of $360 \mathrm{~min}$. The criteria of specific and non-specific $\left[{ }^{3} \mathrm{H}\right]$ ouabain binding [23], as demonstrated for binding to chick heart muscle cells in culture [24], can also be applied to $\left[{ }^{3} \mathrm{H}\right]$ ouabain binding to rat heart muscle cells in culture: unspecific binding is present at high $\left(10^{-3} \mathrm{M}\right)$ ouabain concentrations ( $\mathbf{\Delta}-\mathbf{\Delta}$, Fig. 2), occurs at heat-denatured cells (Table 1 ) and is independent of the presence of $\mathrm{K}^{+}(\odot-\odot$, Fig. $3 \mathrm{~b})$. Specific $\left[{ }^{3} \mathrm{H}\right]-$ ouabain birding ( $\square-\square$, Fig. 2) can then be obtained by subtractior. of unspecific binding from total ouabain binding (Fig. 2); it can be abolished by increasing the $\mathrm{K}^{+}$concentrations in the incubation medium (-) Fig. 3a; $\boldsymbol{\Delta}-\boldsymbol{\Delta}$, Fig. 3b) and is lost after heat denaturation of the cells (Table 1 ). Specific $\left[{ }^{3} \mathrm{H}\right]$ ouabain binding ( $-\odot-\odot$, Fig. 2), is almost completed within $30 \mathrm{~min}$, the amount of specifically bound $\left[{ }^{3} \mathrm{H}\right]$ ouabain thereafter being stable during the whole incubation period of $360 \mathrm{~min}$.

Similar kinetics of specific $\left[{ }^{3} \mathrm{H}\right]$ ouabain binding were also found for cultured rat heart non-muscle cells (results not shown), the amount of specifically bound $\left[{ }^{3} \mathrm{H}\right]$ ouabain being lower and the percentage of non-specific $\left[{ }^{3} \mathrm{H}\right]$ ouabain being higher than in rat

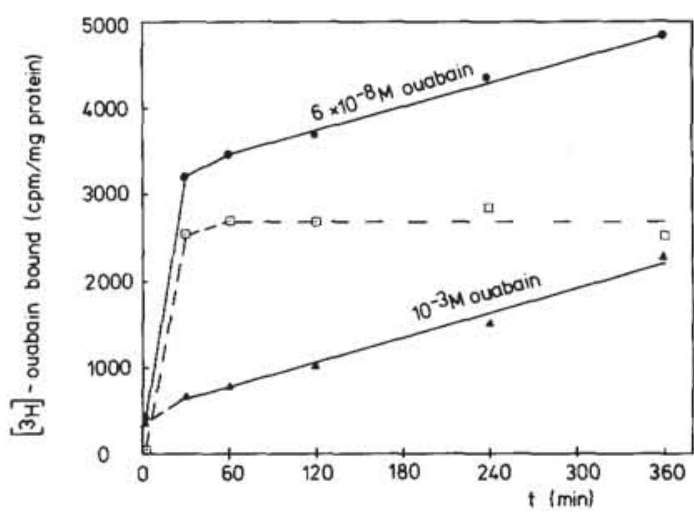

Fig. 2. Kinetics of $\left[{ }^{3} \mathrm{H}\right]$ ouabain binding to cultured heart muscle cells from neonatal rats. For preparation and cultivation of cardiac muscle cells, the hearts of 101 neonatal rats (1-3-days-old) were used. Cells were seeded in 63 plastic culture flasks $\left(25 \mathrm{~cm}^{2}\right.$ each) at a cell density of $55,000 / \mathrm{cm}^{2}$. Cells in serum-supplemented $(2.5 \%$ fetal calf serum, $2.5 \%$ horse serum), HEPES-buffered CMRL 1415 ATM medium $\left(\left[\mathrm{K}^{+}\right]=0.75 \mathrm{mM}\right)$ at $37^{\circ}$ were incubated with $\left[{ }^{3} \mathrm{H}\right]$ ouabain for the times indicated (see abscissa), the total ouabain concentration being $6 \times 10^{-8}(-)$ ) and $10^{-3}(\boldsymbol{\Lambda}-\mathbf{\Lambda})$ $\mathrm{M}$, respectively $\left(3.2 \times 10^{6} \mathrm{cpm} /\right.$ flask; $0.31 \mathrm{mg}$ protein/flask; incubation volume $4.1 \mathrm{ml}$ ). At the times indicated, noncell-bound $\left[{ }^{3} \mathrm{H}\right]$ ouabain was removed by repeated washing of the cells, and the cell-bound radioactivity was determined. For calculation of specific $\left[{ }^{3} \mathrm{H}\right]$ ouabain binding (ㄴ-口), cell-bound $\left[{ }^{3} \mathrm{H}\right]$ radioactivity in the presence of $10^{-3} \mathrm{M}$ ouabain was subtracted from cell-bound $\left[{ }^{3} \mathrm{H}\right] \mathrm{radio}-$ activity in the presence of $6 \times 10^{-8} \mathrm{M}$ ouabain. Values are given as the mean from closely correlating triplicates.

heart muscle cells. Again, specific binding was reduced in the presence of increasing $\mathrm{K}^{+}$concentrations $(x-x$, Fig. $3 a)$.

Table 1. Comparison of $\left[{ }^{3} \mathrm{H}\right]$ ouabain binding in normal and heat-shocked rat heart muscle cells

\begin{tabular}{|c|c|c|}
\hline & Control & Heat-shocked cells \\
\hline \multicolumn{3}{|l|}{$\begin{array}{l}{\left[{ }^{3} \mathrm{H}\right] \text { ouabain binding at }} \\
\text { (cpm/mg protein) }\end{array}$} \\
\hline $9 \times 10^{-8} \mathrm{M}$ & 4050 & 678 \\
\hline $10^{-6} \mathrm{M}$ & 1807 & 614 \\
\hline $10^{-3} \mathrm{M}$ & 908 & 769 \\
\hline $\begin{array}{l}\left({ }^{86} \mathrm{Rb}^{+}+\mathrm{K}^{+}\right) \text {-Uptake } \\
\quad(\mathrm{nmole} / \mathrm{mg} \text { protein } \times \text { min })\end{array}$ & 17.6 & 0.1 \\
\hline $\begin{array}{r}\text { Cell protein } \\
(\mathrm{mg} / \text { flask })\end{array}$ & 1.0 & 0.81 \\
\hline
\end{tabular}

Heart muscle cells were incubated for $60 \mathrm{~min}$ in standard medium (see Materials and Methods) at $37^{\circ}$ (control) and $60^{\circ}$ (heat-shocked cells), respectively (incubation $\mathrm{A}$ ).

$\left[{ }^{3} \mathrm{H}\right]$ ouabain binding: After incubation $\mathrm{A},\left[{ }^{3} \mathrm{H}\right]$ ouabain $\left(4.5 \times 10^{6} \mathrm{cpm} /\right.$ flask) and unlabelled ouabain were added to the standard medium, giving final concentrations of $9 \times 10^{-8}, 10^{-6}$ and $10^{-3} \mathrm{M}$, respectively. Cell-bound $\left[{ }^{3} \mathrm{H}\right]$ ouabain was determined after $4 \mathrm{hr}$ of $\left[{ }^{3} \mathrm{H}\right]$ ouabain incubation at $37^{\circ}$.

$\left({ }^{86} \mathrm{Rb}^{+}+\mathrm{K}^{+}\right)$-Uptake: After incubation A, cells were incubated for a further $4 \mathrm{hr}$ in standard medium at $37^{\circ}$. Thereafter, ${ }^{86} \mathrm{Rb}^{+}\left(2.8 \times 10^{6} \mathrm{cpm} /\right.$ flask) was added, and uptake was measured for $10 \mathrm{~min}$ at $37^{\circ}$.

During all incubation procedures, $\mathrm{K}^{+}$concentration was kept at $0.75 \mathrm{mM}$. 


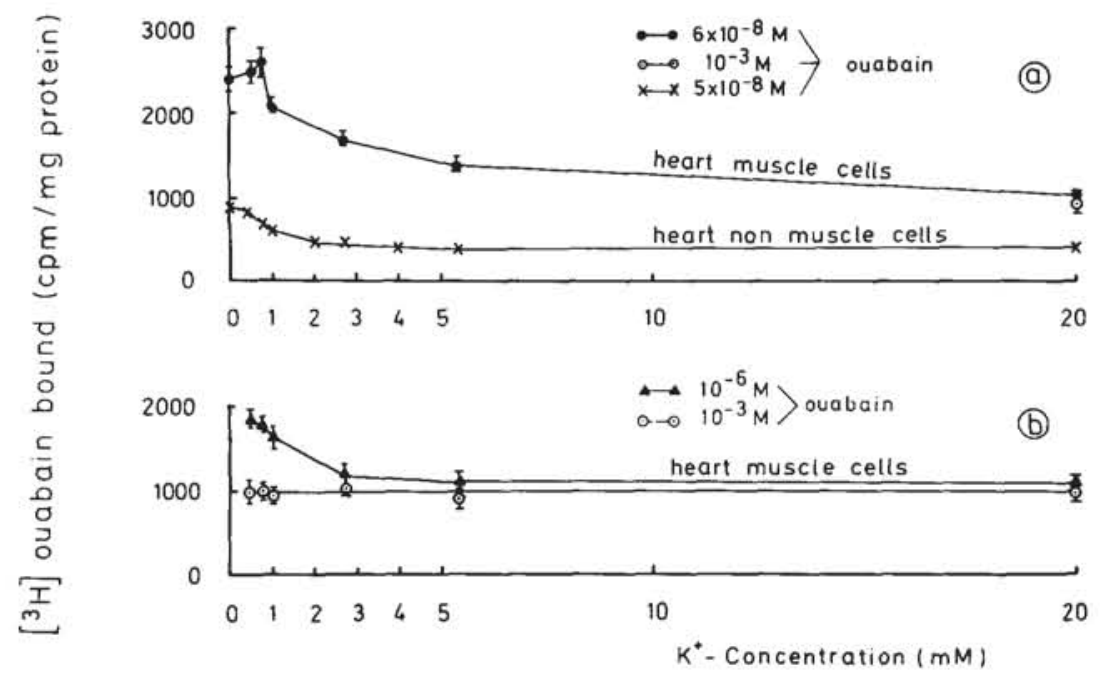

Fig. 3. $\left[{ }^{3} \mathrm{H}\right]$ ouabain binding to cultured cardiac muscle and non-muscle cells from neonatal rats: the influence of potassium ions. For preparation and cultivation of cardiac muscle cells, the hearts of 59 (experiment a) and 79 (experiment b) neonatal rats (1-3-days-old) were used. Cells were seeded in 48 (47) plastic culture flasks $\left(25 \mathrm{~cm}^{2}\right.$ each) at a cell density of $48,000(81,000) / \mathrm{cm}^{2}$. Heart non-muscle cells (experiment a) were obtained from the hearts of 103 neonatal rats (1-2-days-old), after one subcultivation, and were seeded in 40 plastic culture flasks $\left(25 \mathrm{~cm}^{2}\right.$ each). Cells were incubated for $4 \mathrm{hr}$ in standard medium with $\mathrm{K}^{+}$and $\left[{ }^{3} \mathrm{H}\right]$ ouabain concentrations as indicated. Temperature $37^{\circ}$. Thereafter, cell-bound $\left[{ }^{3} \mathrm{H}\right]$ radioactivity was determined. Radioactivity and cell protein/flask (incubation volume $4.1 \mathrm{ml}$ ): experiment a: heart muscle cells $3.6 \times 10^{6} \mathrm{cpm} ; 0.78 \mathrm{mg}$; heart non-muscle cells $2.8 \times 10^{6} \mathrm{cpm} ; 0.52 \mathrm{mg}$; experiment b: $3.8 \times 10^{6} \mathrm{cpm} ; 1.81 \mathrm{mg}$. Values are mean \pm S.D. $(n=3)$ for heart muscle cells, and means from closely correlating duplicates for non-muscle cells.

Quantification of the number of ouabain binding sites in cardiac muscle and non-muscle cells from neonatal rats

Specific $\left[{ }^{3} \mathrm{H}\right]$ ouabain binding was characterized further by measurement of concentration-dependent $\left[{ }^{3} \mathrm{H}\right]$ ouabain binding under equilibrium conditions (Fig. 4a). In cultured cardiac cells from chicken embryos, saturable binding of $\left[{ }^{3} \mathrm{H}\right]$ ouabain to a single class of binding sites $\left(K_{D}=1-2 \times 10^{-7} \mathrm{M}\right)$ has been demonstrated $[24,25]$. Applying exactly the same experimental procedure to $\left[{ }^{3} \mathrm{H}\right]$ ouabain binding in rat heart muscle cells, a biphasic binding curve was obtained (Fig. 4a): after reaching a plateau around $10^{-7} \mathrm{M}$, ouabain binding increased again up to $10^{-5} \mathrm{M}$ ouabain.

Plotting these binding data according to Scatchard [20], a curved line was obtained (Fig. 4b). As there was no experimental evidence for negative cooperativity of ouabain binding to the cells (see next section), more than one class of ouabain binding sites must exist in rat heart muscle cells in culture. Applying the computer program of Weidemann et al. [22], the binding data were compatible with the presence of two classes of ouabain binding sites: a high affinity $\left(K_{D}=7.5 \times 10^{-8} \mathrm{M}\right)$, low capacity $(B=$ $0.2 \mathrm{pmole} / \mathrm{mg}$ protein) binding site, as well as a low affinity $\left(2.3 \times 10^{-5} \mathrm{M}\right)$, high capacity $(5.3 \mathrm{pmole} / \mathrm{mg}$ protein) binding site. Mean values for the dissociation constantsand binding capacitiesfor bothsitesobtained from eight experiments as described in Fig. 4, are given in table 2 .

Also in cultured non-muscle cells prepared from hearts of neonatal rats, two classes of ouabain bind- ing sites were identified, with similar dissociation constants but lower binding capacities than the rat heart muscle cells (Table 2).

Characterization of the association and dissociation processes of specific $\left[{ }^{3} \mathrm{H}\right]$ ouabain binding in rat heart muscle cells in culture

Before describing the characteristics of association and dissociation kinetics, some theoretical considerations will be briefly summarized.

In chick heart muscle cells in culture, the association of ouabain to and the dissociation of ouabain from a single class of binding sites results in monophasic second order and first order kinetics, respectively [24]. The existence of two types of binding sites-as suggested for rat heart muscle cells according to concentration-dependent ouabain binding under equilibrium conditions (Fig. 4)-should be reflected by biphasic dissociation kinetics, the amount of ouabain dissociating from high and low affinity sites being dependent on the ouabain concentration chosen during the preincubation period. The ratios of $\left[{ }^{3} \mathrm{H}\right]$ ouabain radioactivity bound to high and low affinity binding sites can be calculated for every ouabain concentration from the values of the dissociation constants and binding capacities (Table 2 ), applying the law of mass action (see legend to Fig. 8). For different ouabain concentrations, the following ratios (high affinity/low affinity ouabain binding) were calculated: $10^{-8} \mathrm{M}: 13.0 ; 10^{-7} \mathrm{M}: 4.2$; $10^{-6} \mathrm{M}: 0.6 ; 10^{-5} \mathrm{M}: 0.13$.

Figure 5a shows the kinetics of $\left[{ }^{3} \mathrm{H}\right]$ ouabain binding at $37^{\circ}$ to rat heart muscle cells in culture. The 

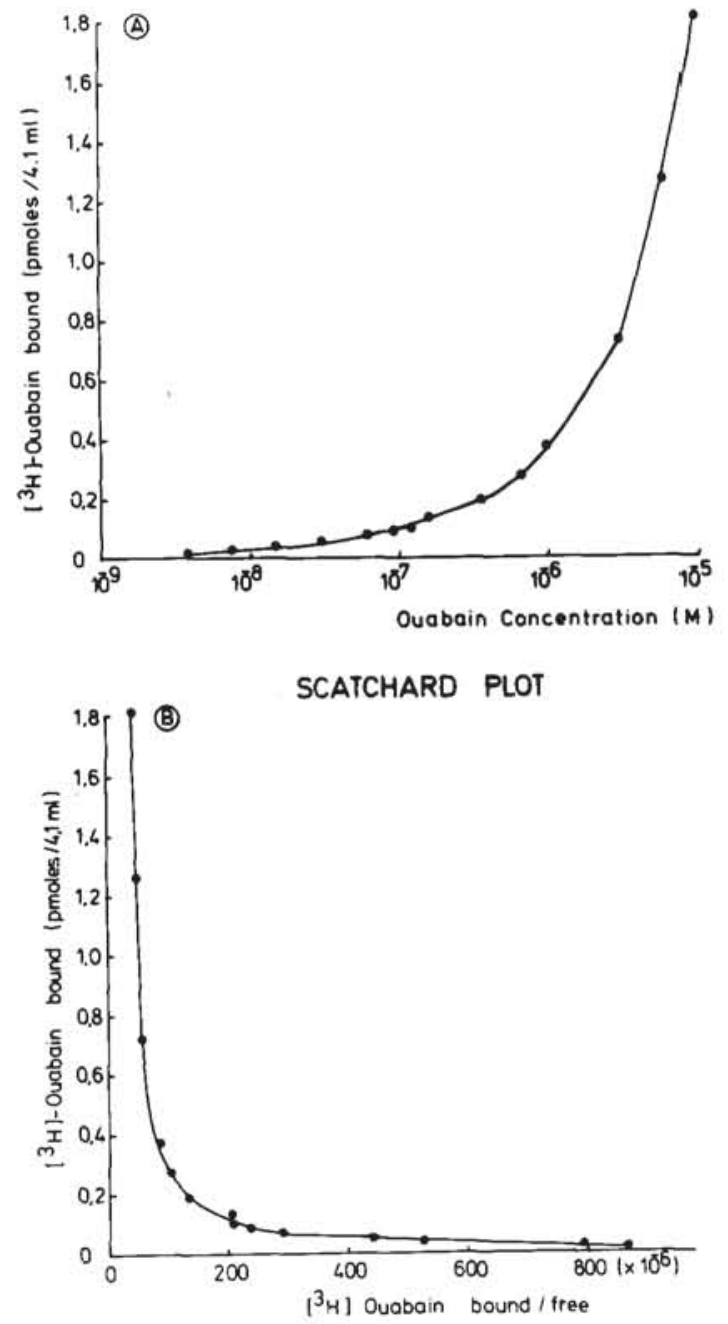

Fig. 4. Concentration dependence of $\left[{ }^{3} \mathrm{H}\right]$ ouabain binding to cultured heart muscle cells from neonatal rats. (a) For preparation and cultivation of cardiac muscle cells, the hearts of 103 neonatal rats (1-2-days-old) were used. Cells were seeded in 73 plastic culture flasks $\left(25 \mathrm{~cm}^{2}\right.$ each) at a cell density of $58,000 / \mathrm{cm}^{2}$. For measurement of $\left[{ }^{3} \mathrm{H}\right]$ ouabain binding, cells were incubated for $4 \mathrm{hr}$ in serum-supplemented, HEPES-buffered CMRL medium $\left(\left[\mathrm{K}^{+}\right]=0.75\right.$ $\mathrm{mM})$ in the presence of $\left[{ }^{3} \mathrm{H}\right]$ ouabain concentrations as indicated (see abscissa). Temperature $37^{\circ}$; incubation volume $4.1 \mathrm{ml} ; 1.03 \mathrm{mg}$ protein/fiask. [ $\left.{ }^{3} \mathrm{H}\right]$ Ouabain radioactivity/flask: $0.2 \times 10^{6} \mathrm{cpm}$ ([ouabain] $=3.9 \times 10^{-9}$ M) $, 0.4 \times 10^{6} \mathrm{cpm}\left(7.8 \times 10^{-9} \mathrm{M}\right), 0.8 \times 10^{6} \mathrm{cpm}(1.6 \times$ $\left.10^{-8} \mathrm{M}\right), 1.7 \times 10^{6} \mathrm{cpm}\left(3.1 \times 10^{-8} \mathrm{M}\right), 3.4 \times 10^{6} \mathrm{cpm}$ $\left(\geqslant 6.2 \times 10^{-8} \mathrm{M}\right)$. For calculation of specific $\left[{ }^{3} \mathrm{H}\right]$ ouabain binding, unspecific binding at $10^{-3} \mathrm{M}$ ouabain $(17 \%$ of maximal counts bound) was subtracted from total $\left[{ }^{3} \mathrm{H}\right]$ ouabain binding. (b) Scatchard plot analysis [20] of binding data presented in (a). Analysis according to Weidemann $e t$ al. [22] for two classes of binding sites yields the following values: $K_{D_{1}}=7.5 \times 10^{-8} \mathrm{M}, B_{1}=0.2 \mathrm{pmole} / \mathrm{mg}$ protein; $K_{D_{2}}=2.3 \times 10^{-5} \mathrm{M}, B_{2}=5.3$ pmole $/ \mathrm{mg}$ protein. Values are means from closely correlating duplicates.

ouabain concentration chosen was $8.7 \times 10^{-8} \mathrm{M}$, the binding process therefore representing mainly binding of ouabain to the high affinity binding site (see above). The association process can be described by second-order kinetics, fitting the following equation [26]:

$$
k_{+1}=\frac{2.303}{(a-b) t} \times \log \frac{b(a-x)}{a(b-x)}
$$

where $a$ is the initial concentration of ouabain in the incubation medium, $b$ is the concentration of high affinity binding sites (see legend to Fig. 5), and $x$ is the concentration of ouabain-high affinity binding site complexes after reaction time $t$. The association rate constant, $k_{+1}$, of the high affinity binding site can then be roughly estimated from the slope of the curve presented in Fig. $5 \mathrm{c}$; it was $1.2 \times 10^{4} \mathrm{M}^{-1} \mathrm{~s}^{-1}$.

In Fig. 5b, rat heart muscle cells were incubated for 4 hr at $8.7 \times 10^{-8} \mathrm{M}$ ouabain, representing equilibrium conditions for ouabain binding. Thereafter, dissociation of $\left[{ }^{3} \mathrm{H}\right]$ ouabain from the cells was measured at different intervals up to $360 \mathrm{~min}$ at $37^{\circ}$. The dissociation process is characterized by a biphasic curve, fitting dissociation from two classes of binding sites by first-order kinetics (Fig. 5d). The dissociation rate constants were estimated from the slopes of the curve and were $9 \times 10^{-4} \mathrm{~s}^{-1}\left(t_{1 / 2}=12 \mathrm{~min}\right)$ and $2 \times 10^{-5} \mathrm{~s}^{-1}\left(t_{1 / 2}=575 \mathrm{~min}\right)(a=$ amount of ouabainbinding site complexes at $t=0, x=$ amount of ouabain dissociated from its binding sites after reaction time $t[26])$. It should be emphasized that due to methodological limitations the dissociation rate constant of the fast component may be even higher and consequently its half-time even shorter than the values measured. In the experiment of Fig. $5 \mathrm{~b}, \mathrm{ca}$ $25 \%$ of specifically bound ouabain rapidly dissociated from the cells. This is in good agreement with the amount of ouabain initially bound to low affinity sites (calculated as $17 \%$, applying the values of Table 2). High concentrations of ouabain $\left(10^{-4}\right.$ $10^{-3} \mathrm{M}$ ) did not alter the dissociation process (results not shown). Therefore, the existence of negative cooperativity between the ouabain binding sites can be excluded [21].

In conclusion, the results of ouabain association (second-order kinetics) and dissociation (biphasic first-order kinetics) experiments are in agreement with the binding of ouabain to two classes of binding sites with different dissociation velocities.

The reduction of $\left[{ }^{3} \mathrm{H}\right]$ ouabain binding under equilibrium conditions by $\mathrm{K}^{+}$(Figs. $3 \mathrm{a}$ and $3 \mathrm{~b}$ ) in rat heart muscle cells can be explained by the $\mathrm{K}^{+}$-induced decrease in association velocity, which was reduced to $25 \%$ of the control value $\left(\left[\mathrm{K}^{+}\right]=0.75 \mathrm{mM}\right)$ in the presence of $3.5 \mathrm{mM} \mathrm{K}^{+}$([ouabain] $=6.7 \times 10^{-8} \mathrm{M}$; association time $=3 \mathrm{~min}$; temperature $37^{\circ}$; results not shown). On the other hand, dissociation of ouabain from its binding sites was not influenced by $\mathrm{K}^{+}$ ions (preincubation of the cells at $8.7 \times 10^{-8} \mathrm{M}$ $\left[{ }^{3} \mathrm{H}\right]$ ouabain; measurement of dissociation between $t=5 \mathrm{~min}$ and $t=720 \mathrm{~min}$; dissociation at $\left[\mathrm{K}^{+}\right]=$ $0.75 \mathrm{mM} ; 1325 \mathrm{cpm} / \mathrm{mg}$ protein; at $\left[\mathrm{K}^{+}\right]=5.4 \mathrm{mM}$; $1360 \mathrm{cpm} / \mathrm{mg}$ protein; $12,700 \mathrm{cpm} /$ pmole ouabain; results not shown).

Binding of $\left[{ }^{3} \mathrm{H}\right]$ ouabain to and dissociation from its specific binding sites was strongly temperaturedependent, with $Q_{10}$ values of $c a 3$ within the temperature range $9^{\circ}$ and $37^{\circ}$ ([ouabain] $=6.7 \times 10^{-8} \mathrm{M}$; results not shown). 
Table 2. Properties of high and low affinity ouabain binding sites in cultured cardiac muscle and non-muscle cells prepared from neonatal rats

\begin{tabular}{|c|c|c|}
\hline & \multicolumn{2}{|c|}{ Rat heart } \\
\hline & Muscle cells & Non-muscle cells \\
\hline $\begin{array}{l}\text { Ouabain binding sites } \\
\text { High affinity binding site } \\
\text { Dissociation constant, } K_{D}(\mathrm{M}) \\
\text { Binding capacity (pmole/mg protein) } \\
\qquad \begin{array}{c}\text { (sites/cell) }\end{array}\end{array}$ & $\begin{array}{l}(3.2 \pm 2.0) \times 10^{-8} \\
0.2 \pm 0.1 \\
8 \times 10^{4}\end{array}$ & $\begin{array}{l}\sim 10^{-8} \\
\sim 0.1\end{array}$ \\
\hline $\begin{array}{l}\text { Low affinity binding site } \\
\text { Dissociation constant, } K_{D}(\mathrm{M}) \\
\text { Binding capacity (pmole/mg protein) } \\
\qquad \begin{array}{c}\text { (sites/cell) }\end{array}\end{array}$ & $\begin{array}{c}(7.1 \pm 3.0) \times 10^{-6} \\
2.6 \pm 0.6 \\
10^{6}\end{array}$ & $\begin{array}{l}\sim 10^{-6} \\
\sim 1\end{array}$ \\
\hline $\begin{array}{l}\text { Ouabain-induced inhibition of } \\
\left.{ }^{86} \mathrm{Rb}^{+}+\mathrm{K}^{+}\right) \text {-uptake }\left(\mathrm{EC}_{50}, \mathrm{M}\right) \\
\text { Ouabain-induced decrease in cell- } \mathrm{K}^{+} \\
\left(\mathrm{EC}_{50}, \mathrm{M}\right)\end{array}$ & $\begin{array}{l}(1.3 \pm 0.2) \times 10^{-5} \\
(1.9 \pm 0.4) \times 10^{-5}\end{array}$ & $\begin{array}{l}(1.5 \pm 0.3) \times 10^{-5} \\
(1.4 \pm 0.3) \times 10^{-5}\end{array}$ \\
\hline $\begin{array}{l}\text { Ouabain-induced increase in cell- } \mathrm{Na}^{+} \\
\left(\mathrm{EC}_{50}, \mathrm{M}\right)\end{array}$ & $10^{-5}-10^{-4}$ & $10^{-5}-10^{-4}$ \\
\hline
\end{tabular}

Data were obtained from experiments as described in Figs. 4 and 6. Ouabain binding sites: values are given as mean \pm S.E.M. ( $n=8$ for muscle cells and $n=4$ for non-muscle cells). Ouabain-induced inhibition of $\left({ }^{86} \mathrm{Rb}^{+}+\mathrm{K}^{+}\right)$-influx: values are mean \pm S.E.M. $(n=8$ for muscle cells and $n=4$ for non-muscle cells). Ouabain-induced decrease in cell- $\mathrm{K}^{+}$: values are mean \pm S.E.M. ( $n=7$ for muscle cells and $n=4$ for non-muscle cells). Ouabain-induced increase in cell- $\mathrm{Na}^{+}: n=5$ (muscle cells); $n=1$ (non-muscle cells).

Correlation of specific ouabain binding and inhibition of active $\left({ }^{86} \mathrm{Rb}^{+}+\mathrm{K}^{+}\right)$-influx in cardiac muscle and non-muscle cells from neonatal rats

The existence of different classes of ouabain binding sites in cultured rat heart cells raises the question whether ouabain-induced inhibition of active $\left({ }^{86} \mathrm{Rb}^{+}+\mathrm{K}^{+}\right)$-influx can be attributed to the binding of ouabain either to the high affinity or to the low affinity binding site.

In order to clarify this question experimentally, cardiac muscle and non-muscle cells from neonatal rats were incubated at different ouabain concentrations under the same conditions as those used for the measurement of $\left[{ }^{3} \mathrm{H}\right]$ ouabain binding (incubation period $\left.4 \mathrm{hr}, 37^{\circ},\left[\mathrm{K}^{+}\right]=0.75 \mathrm{mM}\right)$. In both cell types (Figs. $6 \mathrm{a}$ and $6 \mathrm{~b}) \cdot\left({ }^{86} \mathrm{Rb}^{+}+\mathrm{K}^{+}\right)$-uptake was inhibited by ouabain in a concentration-dependent manner. In addition, a slight increase in the transport rate was observed at low ouabain concentrations in some of the experiments. Maximal inhibition was more than $90 \%$, demonstrating that, at this low $\mathrm{K}^{+}$concentration, more than $90 \%$ of the $\left({ }^{86} \mathrm{Rb}^{+}+\mathrm{K}^{+}\right)$-influx represented active transport mediated by the sodium pump. Half-maximal inhibition in both cell types occurred at $c a 1.5 \times 10^{-5} \mathrm{M}$ ouabain (see also Table 2). As a consequence of ouabain-induced inhibition of active cation transport, the cellular sodium concentration increased, and the cellular potassium concentration decreased, the $\mathrm{EC}_{50}$ values being close to the ouabain concentration producing $50 \%$ inhibition of $\left({ }^{86} \mathrm{Rb}^{+}+\mathrm{K}^{+}\right)$-influx (Table 2). A comparison of these results with the dissociation constants of ouabain binding to high and low affinity binding sites (Table 2) implies that a close relationship exists between the occupation of low affinity binding sites by ouabain and the inhibition of the sodium pump.
Further evidence of this close relationship was furnished from experiments where the kinetics of $\left({ }^{86} \mathrm{Rb}^{+}+\mathrm{K}^{+}\right)$-transport inhibition and reactivation were studied (Fig. 7).

Rat heart muscle cells were incubated in $10^{-5} \mathrm{M}$ ouabain for $210 \mathrm{~min}$. In parallel, $\left({ }^{86} \mathrm{Rb}^{+}+\mathrm{K}^{+}\right)$-influx rates were measured at different time intervals of the incubation period (for experimental details see legend to Fig. 7). Within the first 3 min of ouabain incubation, the $\left({ }^{86} \mathrm{Rb}^{+}+\mathrm{K}^{+}\right)$-influx rate decreased from 12.2 to 8.4 pmole $/ \mathrm{mg}$ protein $\times$ $\mathrm{min}$, then remaining at this level as long as ouabain was present in the incubation medium. At $t=$ $210 \mathrm{~min}$, cells were washed in ouabain-free medium, and the $\left({ }^{86} \mathrm{Rb}^{+}+\mathrm{K}^{+}\right)$-influx rates were again determined at different intervals for the next $240 \mathrm{~min}$. Within the first 4 min of the wash-out phase, ouabaininduced inhibition of $\left({ }^{86} \mathrm{Rb}^{+}+\mathrm{K}^{+}\right)$-uptake was completely reversed. Therefore, reactivation of active cation transport parallels the fast component of $\left[{ }^{3} \mathrm{H}\right]$ ouabain dissociation as demonstrated in the experiment of Fig. 5b.

A clearcut relationship of cardiac glycoside receptor occupancy and inhibition of the sodium pump was obtained by simultaneous measurement of $\left[{ }^{3} \mathrm{H}\right]$ ouabain binding and $\left({ }^{86} \mathrm{Rb}^{+}+\mathrm{K}^{+}\right)$-uptake at various ouabain concentrations, within the same experiment; in the experiment of Fig. 8, the dissociation constants $K_{D}$ for ouabain binding were measured as described in Fig. 4. According to the law of mass action, the percentage of high and low affinity binding sites occupied by ouabain have then been calculated (see legend of Fig. 8) and correlated with the rate of ouabain-sensitive $\left({ }^{86} \mathrm{Rb}^{+}+\mathrm{K}^{+}\right)$-uptake and with the amount of ouabain-displaceable cell- $\mathrm{K}^{+}$, at the very same ouabain concentration. Occupation of the high affinity binding site did not inhibit 

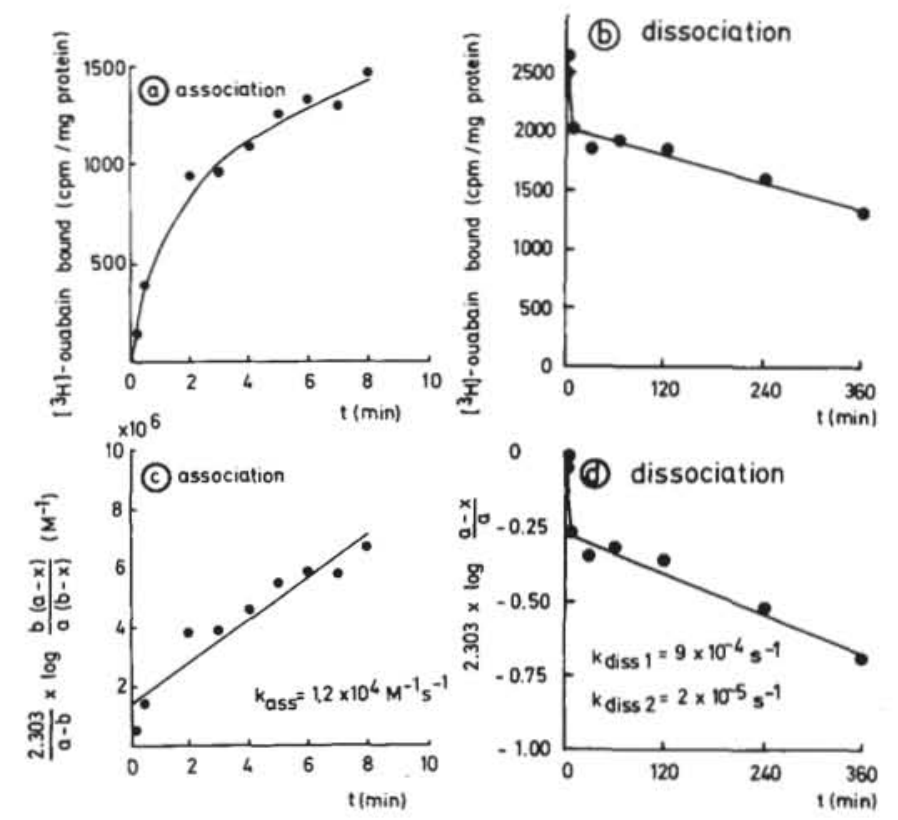

Fig. 5. Determination of association and dissociation rate constants of $\left[{ }^{3} \mathrm{H}\right]$ ouabain binding to cultured rat heart muscle cells. For preparation and cultivation of cardiac muscle cells, the hearts of 107 (association experiment) and 104 (dissociation experiment) neonatal rats (1-3-days-old) were used Cells were seeded in 63 (57) plastic culture flasks at cell densities of 75,000 per $\mathrm{cm}^{2}$. (a) For measurement of ouabain association, muscle cells were preincubated for $4 \mathrm{hr}$ in serum-supplemented, HEPES-buffered CMRL medium $\left(\left[\mathrm{K}^{+}\right]=0.75 \mathrm{mM}\right)$. Thereafter $\left[{ }^{3} \mathrm{H}\right]$ ouabain was added to the medium $\left(4.1 \times 10^{6} \mathrm{cpm} /\right.$ flask), yielding a final ouabain concentration of $8.7 \times 10^{-8} \mathrm{M}$. At the times indicated (see abscissa), noncell-bound $\left[{ }^{3} \mathrm{H}\right]$ ouabain was removed by repeated washing of the cells at $4^{\circ}$ and cell-bound $\left[{ }^{3} \mathrm{H}\right]$ ouabain was determined. Unspecific binding was measured simultaneously in the presence of $10^{-3} \mathrm{M}$ ouabain. Data are given on the ordinate as specific ouabain binding $/ \mathrm{mg}$ protein. Temperature $37^{\circ}$; incubation volume $4.1 \mathrm{ml} ; 1.28 \mathrm{mg}$ protein/flask. Values are given as the mean from closely correlating duplicates. In addition, concentration-dependent, specific $\left[{ }^{3} \mathrm{H}\right]$ ouabain binding under equilibrium conditions with subsequent Scatchard plot analysis was carried out in the experiment of (a), according to the experiment shown in Fig. 4. The following values for the high affinity binding site were obtained: $K_{D}=0.9 \times 10^{-8} \mathrm{M}$ $B=0.23 \mathrm{pmole} / \mathrm{mg}$ protein. (b) For measurement of ouabain dissociation, muscle cells were preincubated with $\left[{ }^{3} \mathrm{H}\right]$ ouabain $\left(4.3 \times 10^{6} \mathrm{cpm} /\right.$ flask, final ouabain concentration $\left.8.7 \times 10^{-8} \mathrm{M}\right)$ for $4 \mathrm{hr}$ at $37^{\circ}$ in serum-supplemented, HEPES-buffered CMRL medium $\left(\left[\mathrm{K}^{+}\right]=0.75 \mathrm{mM}\right)$. Thereafter, cells were washed five times $\left(37^{\circ}\right)$ with incubation medium without ouabain, and were further incubated in ouabainfree medium at $37^{\circ}$. Cell-bound $\left[{ }^{3} \mathrm{H}\right]$ ouabain was measured at the intervals indicated on the abscissa Unspecific $\left[{ }^{3} \mathrm{H}\right]$ ouabain binding was determined simultaneously in the presence of $20 \mathrm{mM} \mathrm{K}$. Data are given as specifically cell-bound $\left[{ }^{3} \mathrm{H}\right]$ ouabain/mg protein (ordinate). Incubation volume $4.1 \mathrm{ml} ; 0.91 \mathrm{mg}$ protein/flask. Values are given as the mean from closely correlating triplicates. In (c) and (d), the data of association (a) and dissociation (b) experiments were plotted to fit the equations for second-order kinetics [(c) association] and first-order kinetics [(d) dissociation], respectively [26]. For further explanation, see text. (c) $a=$ initial concentration of ouabain in incubation medium $\left(8.7 \times 10^{-8} \mathrm{M}\right)$ $b=$ total amount of high affinity ouabain binding sites $/ 4.1 \mathrm{ml}=6.5 \times 10^{-11} \mathrm{M}$ (determined by Scatchard plot analysis); $x=$ amount of ouabain-binding site-complexes $/ 4.1 \mathrm{ml}$ at reaction time $t$. (d) $a=$ total amount of ouabain-binding site-complexes $/ 4.1 \mathrm{ml}$ at $t=0: 4.8 \times 10^{-11} \mathrm{M} \cdot a-x=$ amount of ouabainbinding site-complexes $/ 4.1 \mathrm{ml}$ at reaction time $t$. Calculations were based on the assumption that binding sites of the cells grown as a monolayer were as freely accessible to ouabain molecules during the assay conditions as the binding sites of cells homogeneously suspended in incubation medium. In (c), regression analysis was carried out $\left(y=1.41 \times 10^{6}+7.16 \times 10^{5} x ; r=0.95\right)$. According to second-order kinetics (see text), the curve should intercept at zero. This, however, was not exactly the case, probably due to experimental error. In (d), experimental points were fitted to two regression curves: curve 1: $y=$ $0.012-0.056 x ; r=0.99 ; x=0,1.5$ and $5 \mathrm{~min}$; curve $2: y=-0.223-1.272 \times 10^{-3} x ; r=0.99$; $x=30-360 \mathrm{~min}$.

$\left({ }^{86} \mathrm{Rb}^{+}+\mathrm{K}^{+}\right)$-influx and did not lower cell- $\mathrm{K}^{+}$. Binding of oubain to the low affinity site, however, occurred within approximately the same concentration range as ouabain-induced inhibition of $\left({ }^{86} \mathrm{Rb}^{+}\right.$ $+\mathrm{K}^{+}$)-influx and lowering of cell- $\mathrm{K}^{+}$. Therefore, the low affinity, high capacity binding site may be claimed as the cardiac glycoside receptor with respect to inhibition of the sodium pump. It should be noted, however, that inhibition of active $\mathrm{K}^{+}$-influx seems to occur only when more than $30 \%$ of the low affinity binding sites have bound ouabain (Fig. 8). This may either be due to experimental error (determination of the dissociation constant of the low affinity binding site), or it could reflect the reserve capacity of the sodium pump, as has been shown to exist in chick heart muscle cells in culture [24]. 


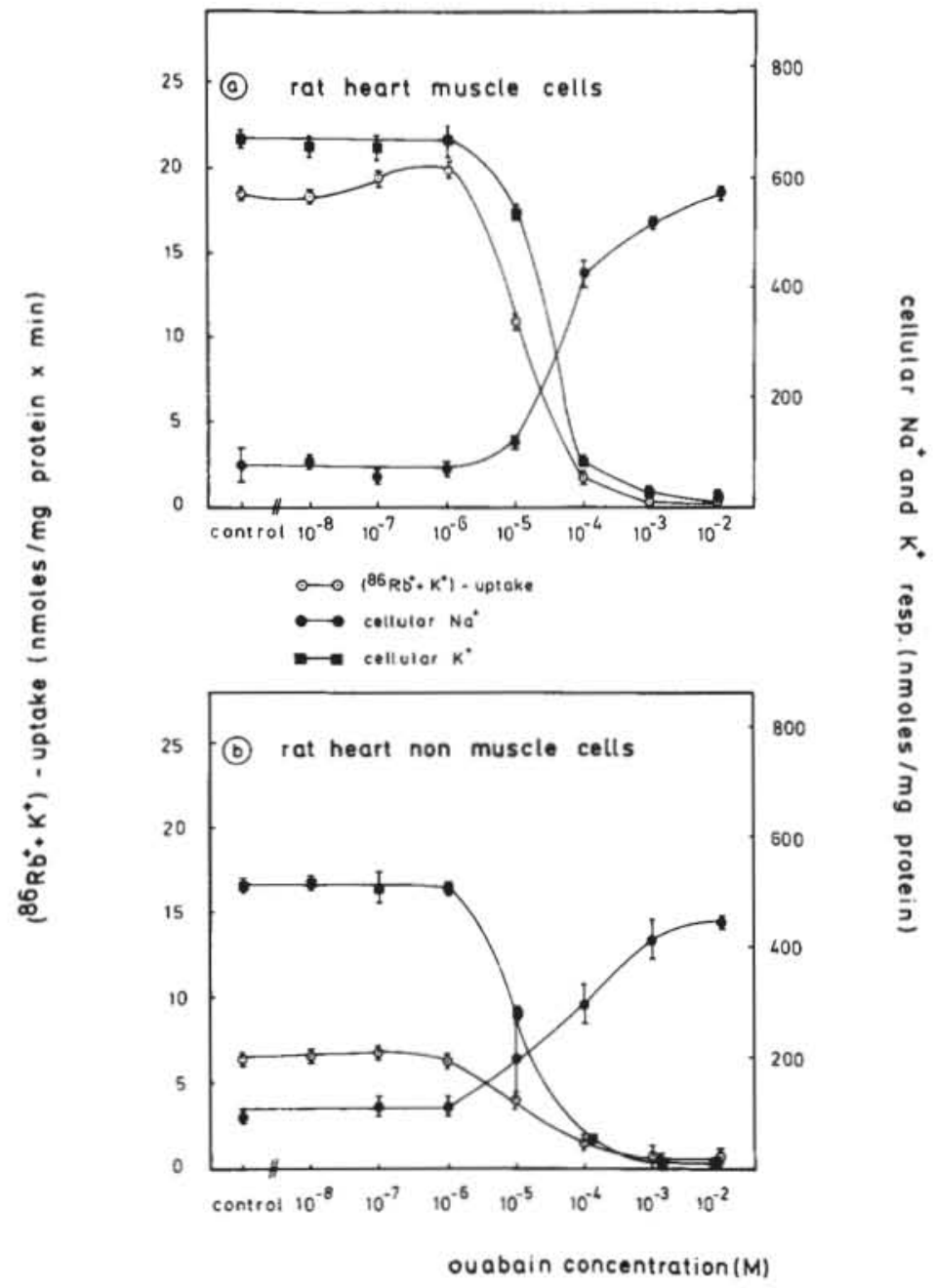

Fig. 6. Effect of ouabain on sodium pump activity in cultured cardiac muscle and non-muscle cells from neonatal rats. For preparation and cultivation of cardiac muscle cells, the hearts of 105 neonatal rats (1-4-days-old) were used. Cells were seeded in 78 plastic culture flasks $\left(25 \mathrm{~cm}^{2}\right.$ each) at a cell density of $80,000 / \mathrm{cm}^{2}$. Heart non-muscle cells were obtained from the hearts of 155 neonatal rats (1-2-daysold) after one sub-cultivation, and were seeded in 80 plastic culture flasks $\left(25 \mathrm{~cm}^{2}\right)$. Muscle (a) and nonmuscle (b) cells were incubated with different ouabain concentrations (see absicissa) in standard medium $\left(\left[\mathrm{K}^{+}\right]=0.75 \mathrm{mM}\right)$ at $37^{\circ}$. Thereafter, the $\left({ }^{86} \mathrm{Rb}^{+}+\mathrm{K}^{+}\right)$-influx rate, cell- $\mathrm{K}^{+}$and cell-Na ${ }^{+}$were determined. Measurement of $\left({ }^{86} \mathrm{Rb}^{+}+\mathrm{K}^{+}\right)$-influx rate: Within the last $10 \mathrm{~min}$ of incubation period, ${ }^{86} \mathrm{Rb}^{+}$was added in tracer amounts to the incubation medium; after 10 min, the amount of ${ }^{86} \mathrm{Rb}^{+}$taken up into the cells was determined. Values were corrected by 'zero-measurements' [15]. Measurement of cell- $\mathrm{K}^{+}$was carried out after the end of incubation period by flame photometry [16]. Measurement of cell- $\mathrm{Na}^{+}$: At the beginning of the incubation period, ${ }^{22} \mathrm{Na}^{+}$was added in tracer amounts to the medium. At the end of the incubation period, the exchangeable pool of ${ }^{22} \mathrm{Na}^{+}$was determined [16]. Radioactivity and cell protein per flask: (a): $2.02 \times 10^{6} \mathrm{cpm}^{86} \mathrm{Rb}^{+} ; 8.98 \times 10^{6} \mathrm{cpm}^{22} \mathrm{Na}^{+} ; 1.30 \mathrm{mg}$. (b): $2.75 \times 10^{6} \mathrm{cpm}$ ${ }^{86} \mathrm{Rb}^{+} ; 10.72 \times 10^{6} \mathrm{cpm}^{22} \mathrm{Na}^{+} ; 0.45 \mathrm{mg}$. Values are given as mean \pm S.E.M. $\left(n=4-16\right.$, cell- $\left.\mathrm{K}^{+}\right)$and mean \pm S.D. $\left[n=3\right.$, cell- $\mathrm{Na}^{+}$and $\left({ }^{86} \mathrm{Rb}^{+}+\mathrm{K}^{+}\right)$-influx rates $\left.]\right)$.

Positive inotropic action of ouabain in rat heart muscle cells in culture

In cultured cardiac muscle cells, the drug-induced increase in the amplitude of cell-wall motion as well as in the velocity of motion is indicative of a positive inotropic effect of this drug [27,28]. The positive inotropic effect of cardiac glycosides has been demonstrated in heart muscle cells in culture from different species $[19,28-30]$.

Figure 9 demonstrates the effect of three concen- trations of ouabain on cell-wall motion of rat heart muscle cells in culture (for experimental details, see legend of Fig. 9). As cardiac glycosides increased their beating frequency, the cells were paced at a constant rate of $100 / \mathrm{min}$ to exclude frequencyinduced staircase phenomena. For a better comparison of the data obtained with the experiments of $\left[{ }^{3} \mathrm{H}\right]$ ouabain binding (Fig. 4) and ouabain-induced sodium pump inhibition (Fig. 6), the cells were perfused with low $\mathrm{K}^{+}(1.5 \mathrm{mM})$ medium. The addition 


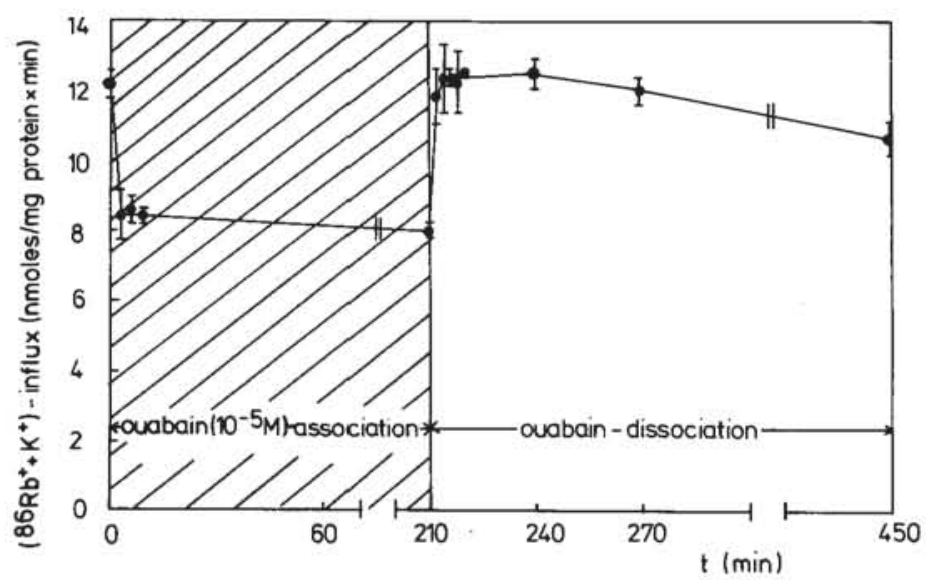

Fig. 7. Kinetics of ouabain-induced inhibition and reactivation of $\left({ }^{86} \mathrm{Rb}^{+}+\mathrm{K}^{+}\right)$-influx rates in rat heart muscle cells in culture. For preparation and cultivation of cardiac muscle cells, the hearts of 97 neonatal rats (1-3-days-old) were used. Cells were seeded in 54 plastic culture flasks $\left(25 \mathrm{~cm}^{2}\right.$ each) at a cell density of 130,000 per $\mathrm{cm}^{2}$. Cells were incubated for $210 \mathrm{~min}$ in $10^{-5} \mathrm{M}$ ouabain in standard medium $\left(\left[\mathrm{K}^{+}\right]=\right.$ $0.75 \mathrm{mM})$. At different time intervals ${ }^{86} \mathrm{Rb}^{+}$was added to the medium in tracer amounts $\left(6.6 \times 10^{5} \mathrm{cpm} /\right.$ flask), and the uptake of ${ }^{86} \mathrm{Rb}^{+}$into the cells was measured for $1 \mathrm{~min}$. At $t=210 \mathrm{~min}$, the cells were washed five times $\left(37^{\circ}\right)$ with ouabain-free incubation medium, and were then incubated further in ouabain-free medium up to $t=450 \mathrm{~min}$. Again, $\left({ }^{86} \mathrm{Rb}^{+}+\mathrm{K}^{+}\right)$-influx rates were determined at different intervals of the dissociation period, as described for the association period. Flux measurements were corrected by 'zero-measurements' [15]. Incubation volume $4.1 \mathrm{ml}$; temperature $37^{\circ} ; 0.35 \mathrm{mg}$ protein/ flask.

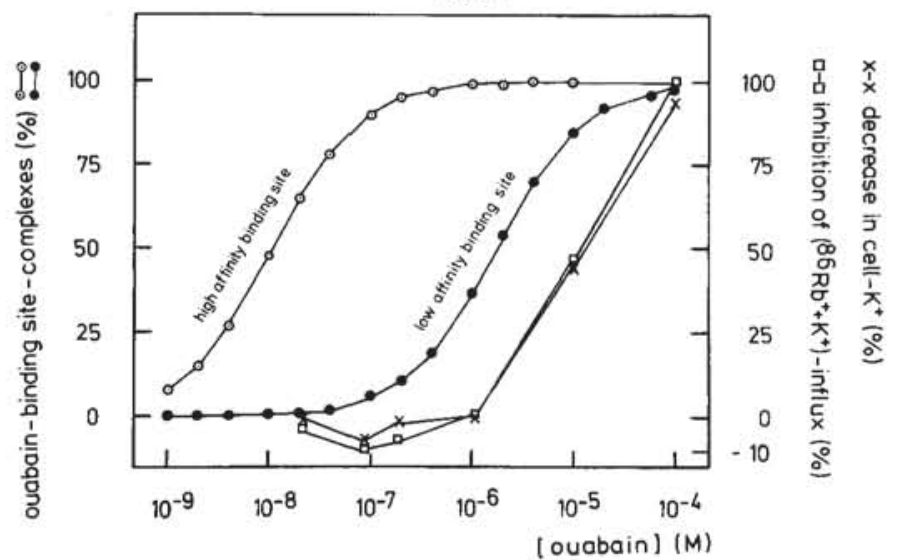

Fig. 8. Effect of $\left[{ }^{3} \mathrm{H}\right]$ ouabain binding to its high and low affinity binding sites on ouabain-sensitive $\left({ }^{86} \mathrm{Rb}^{+}+\mathrm{K}^{+}\right)$-influx rate rate and on cell- $\mathrm{K}^{+}$in cultured cardiac muscle cells from neonatal rats. $\left[{ }^{3} \mathrm{H}\right]$ Ouabain binding was measured and analysed according to Scatchard [20], as described in the experiment of Fig. 4; both $\left({ }^{86} \mathrm{Rb}^{+}+\mathrm{K}^{+}\right)$-uptake and cell- $\mathrm{K}^{+}$were determined as shown in the experiment of Fig. 6, at various ouabain concentrations. According to $K_{D}=[\mathrm{O}] \times[\mathrm{B} V[\mathrm{BO}]$, the percentage of high and low affinity binding sites occupied by ouabain (BO) can be calculated for every ouabain concentration (O) chosen. $[\mathrm{B}]=$ Concentration of free ouabain binding sites = concentration of total binding sites[BO]. The calculation was based on the assumuption that one ouabain binding site binds one molecule of ouabain. Based on the measured $K_{D}$ values (see below) for high and low affinity binding sites, the law of mass action allows construction of the curves for binding site occupancy. $K_{D}$ of high affinity site: $1.1 \times 10^{-8} \mathrm{M} ; K_{D}$ of low affinity binding site: $1.7 \times 10^{-6} \mathrm{M}$. For measurement of $\left({ }^{86} \mathrm{Rb}^{+}+\mathrm{K}^{+}\right)$-uptake and cell $-\mathrm{K}^{+}$, values are given as mean from closely correlating duplicates. For preparation and cultivation of cardiac muscle cells, the hearts of 85 neonatal rats (1-3-days-old) were used. Cells were seeded in 60 plastic culture flasks $\left(25 \mathrm{~cm}^{2}\right.$ each) at a cell density of 65,000 per $\mathrm{cm}^{2}$. Temperature $37^{\circ}$; incubation volume $4.1 \mathrm{ml} ; 0.7 \mathrm{mg}$ protein/flask; $\left.3.4 \times 10^{6} \mathrm{cpm} \mathrm{[}{ }^{3} \mathrm{H}\right]$ ouabain or $1.8 \times 10^{6} \mathrm{cpm}{ }^{86} \mathrm{Rb}^{+}$per flask. For Scatchard plot analysis, cells were incubated at seven different $\left[{ }^{3} \mathrm{H}\right]$ ouabain concentrations $\left(2 \times 10^{-8}\right.$ $\left.1 \times 10^{-5} \mathrm{M}\right)$ in standard medium $\left(\left[\mathrm{K}^{+}\right]=0.75 \mathrm{mM}\right)$ for $4 \mathrm{hr}$. Unspecific $\left[{ }^{3} \mathrm{H}\right]$ ouabain binding was measured in the presence of $10^{-2} \mathrm{M}$ ouabain ( $15 \%$ of maximal counts bound). For the determination of $\left({ }^{86} \mathrm{Rb}^{+}+\mathrm{K}^{+}\right)$-influx rate and cell- $\mathrm{K}^{+}$, cells were incubated at different ouabain concentrations (see abscissa) in standard medium $\left(\left[\mathrm{K}^{+}\right]=0.75 \mathrm{mM}\right)$. Therafter, ${ }^{86} \mathrm{Rb}^{+}$was added in tracer amounts to the medium, and the uptake of ${ }^{86} \mathrm{Rb}^{+}$into the cells was determined within a 10 min period. Cell- $\mathrm{K}^{+}$was determined at the end of the incubation period by flame photometry. Flux measurements were corrected by 'zero-measurements' [15]. Control values in the absence of ouabain: $\left({ }^{86} \mathrm{Rb}^{+}+\mathrm{K}^{+}\right)$-influx rate: $8.6 \mathrm{nmoles} / \mathrm{mg}$ protein $\times$ min; cell- $\mathrm{K}^{+}: 400 \mathrm{nmole} / \mathrm{mg}$ protein. Values at $10^{-2} \mathrm{M}$ ouabain: $\left({ }^{86} \mathrm{Rb}^{+}+\mathrm{K}^{+}\right)$influx rate: $0.01 \mathrm{nmole} / \mathrm{mg}$ protein $\times$ min; cell- $\mathrm{K}^{+}: 10 \mathrm{nmole} / \mathrm{mg}$ protein. The difference in control values and values at $10^{-2} \mathrm{M}$ ouabain was taken as $100 \%$ of the ouabain effect. 


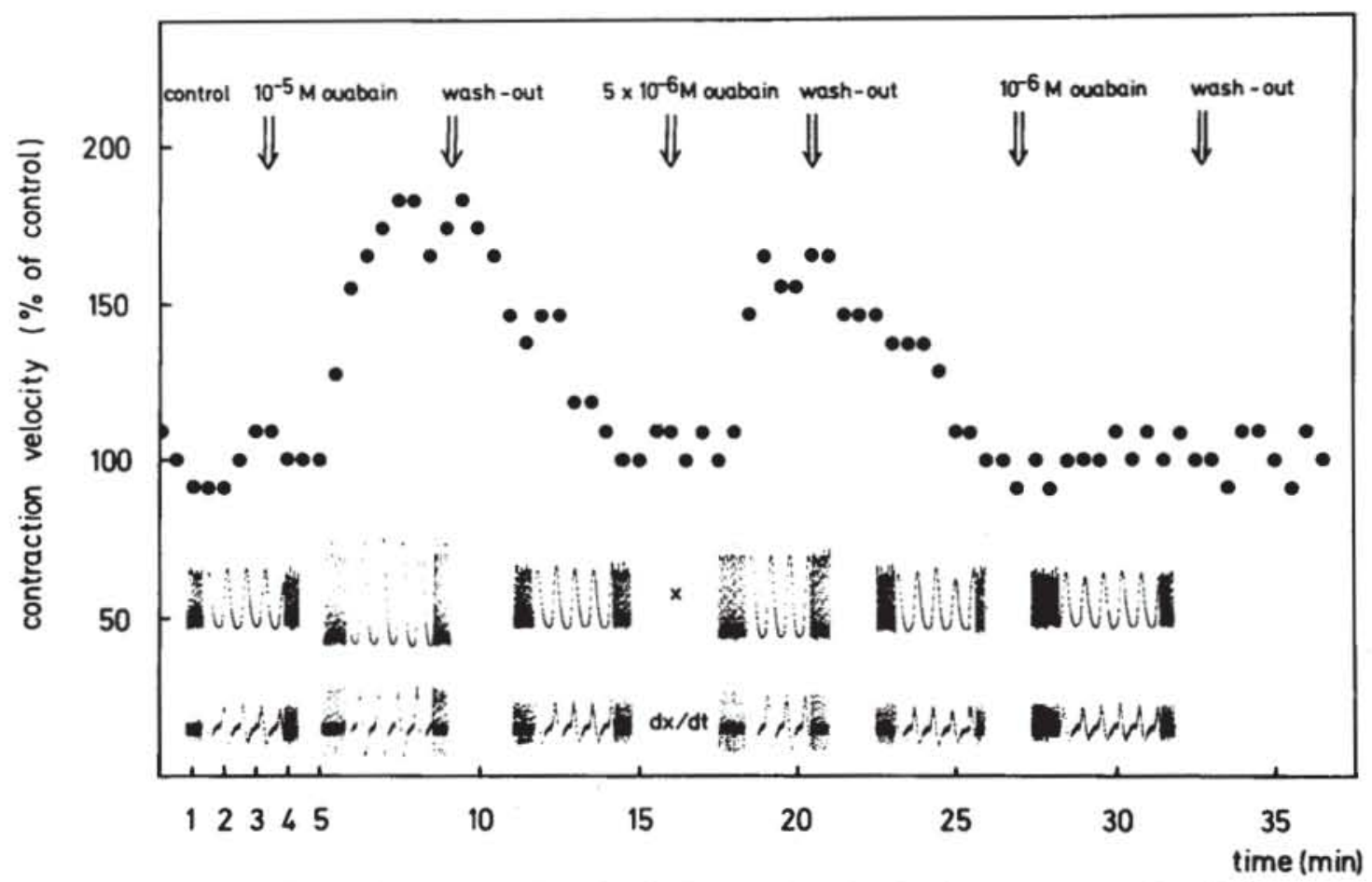

Fig. 9. Effect of ouabain on amplitude and velocity of cell-wall motion in rat heart muscle cells in culture. Heart muscle cells were prepared from neonatal rats as described in Materials and Methods, and thereafter seeded on glass-coverslips at a cell density of $10^{5} \mathrm{cells} / \mathrm{cm}^{2}$. After culturing the cells for 3 days (see Materials and Methods), the coverslips were mounted in a perfusion chamber. Cells were superfused $(4 \mathrm{ml} / \mathrm{min}$ ) continually with serum-free, HEPES-buffered incubation medium [CMRL-1415 with modified $\mathrm{Ca}^{2+}(0.8 \mathrm{mM})$ and $\mathrm{K}^{+}(1.5 \mathrm{mM})$ concentrations] at $37^{\circ}$. Beating of the electrically driven cells (pacing rate $100 / \mathrm{min}, 100 \mathrm{~V}$, pulse duration $10 \mathrm{msec}$ ) was watched under a phase contrast microscope, using an electro-optical monitoring system [15]. At the times indicated, the medium was changed. The amplitude $(x)$ and the velocity of cell-wall motion ( $\mathrm{d} x / \mathrm{d} t$, 'contraction velocity') of a single cell are shown in the figure. During the whole observation period of $35 \mathrm{~min}$, the value for the contraction velocity (arbitrary units) was determined every $30 \mathrm{sec}$. Control $=$ Contraction velocity of the heart muscle cell in the absence of ouabain, given as the mean from measurements during the first $3 \mathrm{~min}$ of the experiment.

of ouabain to the perfusion medium in final concentrations of $10^{-5}$ and $5 \times 10^{-6} \mathrm{M}$ increased the amplitude of cell-wall motion $(x)$ as well as the velocity of cell-wall motion $(\mathrm{d} x / \mathrm{d} t)$, indicating a positive inotropic effect of ouabain. A smaller increase in amplitude and velocity was observed at $5 \times 10^{-6} \mathrm{M}$ than at $10^{-5} \mathrm{M}$ ouabain. At $10^{-6} \mathrm{M}$, no effect of ouabain on cell-wall motion was measurable within a period of $5 \mathrm{~min}$. The ouabain effects could be washed out by superfusing the cells with ouabainfree medium, the half time for the wash-out phase being approximately $2-3 \mathrm{~min}$.

\section{DISCUSSION}

Evidence for two classes of ouabain binding sites in cultured heart muscle cells from neonatal rats

In cultured heart cells from chicken embryos, ouabain binds to a single class of binding sites [24, 25]. Applying the very same experimental procedures for the characterization of ouabain binding in rat heart muscle cells in culture, experimental evidence strongly suggests different types of saturable ouabain binding sites in these cells. This experimental evidence is based on the results of concentration- dependent ouabain binding under equilibrium conditions, and it is further confirmed by kinetic measurements of ouabain binding.

In the absence of negative cooperativity of ouabain binding (see caption to Fig. 5), Scatchard plot analysis suggests the presence of high affinity, low capacity and low affinity, high capacity binding sites (Fig. 4). Biphasic dissociation kinetics demonstrate a fast and slow component (Figs. 5b and 5d), the relative proportions quantitatively representing dissociation of ouabain from low and high affinity binding sites, respectively (see caption to Fig. 5).

The properties of ouabain binding sites in rat heart muscle cells can be described as follows. High affinity sites $\left(K_{D}=3.2 \times 10^{-8} \mathrm{M}\right)$ represent $c a 7 \%$ and low affinity sites $\left(K_{D}=7.1 \times 10^{-6} \mathrm{M}\right) \mathrm{ca} 93 \%$ of total binding sites (Table 2); the total number $\left(1.1 \times 10^{6}\right.$ sites/cell being similar to that found in chick heart muscle cells $\left(860,000\right.$ sites $/$ cell; $K_{D}=$ $\left.1.5 \times 10^{-7} \mathrm{M} ;[25]\right)$. Binding of ouabain to both sites is lowered by $\mathrm{K}^{+}$(Fig. 3) and is destroyed by heat denaturation of the cells (Table 1 ). At $37^{\circ}$, ouabain dissociates from the low affinity binding site with a half time of $\leqslant 12 \mathrm{~min}$ (dissociation rate constant $\geqslant$ $\left.9 \times 10^{-4} \mathrm{sec}^{-1}\right)$, while the high affinity binding site 
releases ouabain very slowly $\left(t_{1 / 2}=575 \mathrm{~min}\right.$, dissociation rate constant $=2 \times 10^{-3} \mathrm{sec}^{-1}$; Fig. 5). $\mathrm{K}^{+}$ reduces the association velocity of high affinity binding, but is without effect on the dissociation process. The temperature dependence of ouabain association to and dissociation from the high affinity binding site $\left(Q_{10} \sim 3\right)$ is of the same order of magnitude as that reported for ouabain binding in chick heart muscle cells in culture [24].

Thus, our results demonstrate the existence of saturable high and low affinity binding sites for ouabain in rat heart muscle cells in culture. As receptor functions, at present, can be attributed only to the low affinity binding site (see next section), some restrictions have to be made, especially with respect to the high affinity site:

(a) Part of the specifically cell-bound ouabain could represent ouabain taken up or being internalized into the cells. Ouabain uptake into the cells via a diffusion process, however, would linearly increase with increasing ouabain concentrations, which is in contrast to the results of the experiment of Fig. 2 (different binding rates for $\left[{ }^{3} \mathrm{H}\right]$ ouabain radioactivity at $6 \times 10^{-8}$ and $10^{-3} \mathrm{M}$ ouabain). On the other hand, saturable carrier-mediated ouabain transport across the cell membrane has been demonstrated only for liver [31] but not for cardiac tissue. In addition, ouabain transport [31] was independent of $\mathrm{K}^{+}$, in contrast to our ouabain binding studies (Fig. 3). According to the criteria of ouabain internalization into cells [32-35], the saturability of specific ouabain binding (Fig. 2), the $\mathrm{K}^{+}$-dependence and the presence of two classes of binding sites not only in intact cells but also in cardiac membranes (Fig. 1) strongly argue against internalization of specifically cellbound ouabain. It seems, on the other hand, possible that part of unspecific, non-saturable ouabain binding (Fig. 2) may represent internalized ouabain or ouabain taken up into the cells. In this case, however, it would not falsify these measurements of ouabain binding to high and low affinity binding sites.

(b) Primary cultures of rat heart muscle cells are contaminated, as an impurity, by non-muscle cells, mainly consisting of fibroblasts and non-muscle cells (see Materials and Methods). Therefore, part of the specific ouabain binding, e.g. the relatively small amount of high affinity binding, could represent ouabain binding to non-muscle cells. This possibility has been excluded under our experimental conditions by studying ouabain binding in pure cultures of nonmuscle cells from neonatal rats (see Materials and Methods, and Table 2).

(c) Two classes of ouabain binding sites have been demonstrated in cardiac membranes from adult [3] and neonatal rats (Fig. 1), as well as in cultured heart muscle cells from neonatal rats (Table 2). However, the affinity of these binding sites for ouabain as well as the relative amount of high and low affinity sites differ to some extent in these preparations: the dissociation constants of the high affinity sites being $1-2.3 \times 10^{-7}, 2.2 \times 10^{-8}$ and $3.2 \times 10^{-8} \mathrm{M}$, respectively, and its relative amount 10,1 and $7 \%$. In the case of the low affinity site, dissociation constants of $2.8 \times 10^{-5}, 1.3 \times 10^{-4}$ and $7.1 \times 10^{-6} \mathrm{M}$ have been obtained. Although part of these differences may be due to different incubation procedures - e.g. equilib- rium conditions for ouabain binding in cardiac cell membranes from neonatal rats (see legend of Fig. 1), measurement of initial peak ouabain binding in case of cardiac cell membranes from adult rats [3]the influence of animal age and cell culture procedures remains to be checked.

Characterization of cardiac glycoside receptors in cultured heart muscle cells from neonatal rats

Does one or do both classes of ouabain binding sites in rat heart muscle cells represent cardiac glycoside receptors? This question can be answered by correlating in these cells occupation of high and low affinity binding sites by ouabain with its positive inotropic action and with its inhibition of the sodium pump.

(a) Correlation of ouabain binding and sodium pump inhibition. In the experiment of Fig. 8, the percentage of ouabain-induced inhibition of $\left.{ }^{86} \mathrm{Rb}^{+}+\mathrm{K}^{+}\right)$-uptake and the concomitant decrease in cell- $\mathrm{K}^{+}$have been plotted vs the occupation of high and low affinity sites by ouabain. It clearly becomes evident that only the occupation of low affinity sites by ouabain is coupled to the inhibition of the sodium pump. This finding is confirmed further by the measurement of reactivation kinetics of $\left({ }^{86} \mathrm{Rb}^{+}+\mathrm{K}^{+}\right)$-influx in the experiment of Fig. 7: within 4 min after starting washout of ouabain, druginduced inhibition of $\left({ }^{86} \mathrm{Rb}^{+}+\mathrm{K}^{+}\right)$-influx was completely reversed, in agreement with the half time for ouabain dissociation from the low affinity binding sites ( $\leqslant 12 \mathrm{~min}$, see legend of Fig. 5).

(b) Correlation of ouabain binding and positive inotropic action of ouabain. Under our experimental conditions, a positive inotropic effect of oubain in electrically driven rat heart muscle cells is clearly seen at $10^{-5}$ and $5 \times 10^{-6} \mathrm{M}$, but not at $10^{-6} \mathrm{M}$ ouabain (Fig. 9). The effects are rapidly and completely reversible within $5 \mathrm{~min}$ after drug washout. Concentration dependence and wash-out kinetics favour the assumption that positive inotropic action of ouabain results from binding to the low affinity binding sites. However, we cannot exclude that the electro-optical system used for measurement of cellwall motion [15] may fail to indicate slight increases in the contraction velocity and the amplitude of cellwall motion in the presence of low concentrations of ouabain (for a discussion of this problem see refs. $[27,28])$. We may therefore overlook small positive inotropic effects if they are coupled to the occupation of high affinity binding sites by ouabain. With this respect it should be mentioned that Okarma et al. [19] have observed positive inotropic effects in cultured rat heart muscle cells at digoxin concentrations of $10^{-9}-10^{-8} \mathrm{M}$.

In conclusion, the low affinity ouabain binding site in rat heart muscle cells, as characterized in this paper, can be classified as the cardiac glycoside receptor, since occupation by ouabain is linked to positive inotropic effects and inhibition of the sodium pump. At present, no receptor function can be attributed to the high affinity ouabain binding site: while measurable coupling of this binding site to sodium pump inhibition can unequivocally be ruled out, the failure to demonstrate a positive inotropic effect may be due to methodological limitations. 
Comparison of cardiac glycoside receptors in rat and chicken heart

The bimodal positive inotropic effect of cardiac glycosides in rat heart is now well established; the concomitant rise in diastolic tension and the occurrence of arrhythmias at the 'high dose' inotropic effect probably being indicative of different mechanisms of inotropic action [3-7]. As a molecular basis of this bimodal inotropic effect, two classes of ouabain binding sites have been identified in $\left(\mathrm{Na}^{+}+\mathrm{K}^{+}\right)$ATPase enriched cardiac membranes from rat heart $[3,4]$. In contrast, only one type of saturable binding sites with high affinity for ouabain has been demonstrated in rat ventricular strips [3] and in rat heart muscle cells $[5,10,11]$, probably due to methodological limitations. Our results now clearly demonstrate the existence of high and low affinity binding sites for ouabain in rat heart muscle and non-muscle cells in culture. The identification of two types of binding sites in the intact rat heart muscle cell rules out the possibility that one class may arise as an artefact due to membrane preparation procedure, or that it may represent ouabain binding to non-muscle constituents (nervous and vascular tissue, fibroblasts) of rat heart.

Regarding all the available data from work with cardiac membranes, heart muscle preparations and heart muscle cells in culture, the functional properties of the low affinity receptor in rat heart seem clear: binding of cardiac glycosides to this receptor increases the force of contraction, inhibits sodium pump activity, and produces toxic effects (arrhythmias, an increase in diastolic tension). The high affinity receptor does not seem to be involved in sodium pump inhibition. A contribution of the high affinity receptor to positive inotropic action could be demonstrated only in rat heart muscle preparations, but not in cultured rat heart muscle cells. It remains to be clarified whether cell culture procedures lead to inactivation of the high affinity receptor, whether the lack of positive inotropic response is due to methodological limitations, or whether the development of the low dose effect ('sensitization' of the high affinity site) in rat heart is age-related. Studying the inotropic effect of ouabain in hearts from neonatal rats will help to answer the latter question. Further open questions are; do high and low affinity receptors represent part of different $\left(\mathrm{Na}^{+}+\mathrm{K}^{+}\right)$ATPase isozymes [4] or interconvertible conformational states of the $\left(\mathrm{Na}^{+}+\mathrm{K}^{+}\right)$-ATPase molecule $[8,9,36]$, or can they be classified as two distinct sites being independent of each other?

Does the existence of two classes of cardiac glycoside receptors represent the exception, being restricted to the rat, or does it represent a more common phenomenon? At least for some species (guinea pig, dog, man), experimental evidence is present for different receptor types [36-40].

Additional evidence may also come from work with cultured heart cells from chicken embryos: recently we have characterized cardiac glycoside receptors in cardiac muscle and non-muscle cells from chicken embryos $[24,25]$. Concerning ouabain binding, a single class of binding sites has been identified in both cell types $\left(K_{D}=1.5 \times 10^{-7} \mathrm{M}\right.$ and $\left.1.9 \times 10^{-7} \mathrm{M}\right)$. Only in cardiac non-muscle cells, however, has a linear correlation been found between the occupation of binding sites and sodium pump inhibition. In cardiac muscle cells from chicken embryos, significant pump inhibition only occurs at receptor occupation of $40 \%$ or more [25]. This could be indicative of the existence of two classes of ouabain binding sites with similar affinities for ouabain, only one of which is coupled to sodium pump inhibition. If this can be experimentally proven, heart muscle cells in culture would provide a simple model for elucidating the general importance of different forms of cardiac glycoside receptors in the intact heart muscle cell, without interference from nervous stimuli and cardiac non-muscle tissue.

Acknowledgements-This work was supported by the Wilhelm Sander-Stiftung (78.014.2) and by the Deutsche Forschungsgemeinschaft (Er 65/4-3). The excellent technical assistance of B. Walther is gratefully acknowledged.

\section{REFERENCES}

1. K. Werdan, B. Zwissler, B. Wagenknecht, W. Krawietz and E. Erdmann, Eur. J. Cell Biol. 27, 33 (1982).

2. D. Noble, Cardiovasc. Res. 14, 495 (1980).

3. E. Erdmann, G. Philipp and H. Scholz, Biochem. Pharmac. 29, 3219 (1980).

4. M. Finet, F. Noel and T. Godfraind, Archs int. Pharmacodyn. 256, 168 (1982).

5. R. J. Adams, A. Schwartz, G. Grupp, I. Grupp, S.-W. Lee, E. T. Wallick, T. Powell, V. H. Twist and P. Gathiram, Nature, Lond. 296, 167 (1982).

6. I. L. Grupp, G. Grupp and A. Schwartz, Life Sci. 29, 2789 (1981)

7. J. M. Koomen, W. H. van Gilst, A. N. E. Zimmerman and J. van Nordwijk, Arch. int. Pharmacodyn. 255, 212 (1982).

8. P. Mansier and L. G. Lelievre, Nature, Lond. 300, 535 (1982).

9. P. Mansier, P. S. Cassidy, D. Charlemagne, M. Preteseille and L. G. Lelievre, FEBS Lett. 153, 357 (1983).

10. D. McCall, Am. J. Physiol. 236, C87 (1979).

11. I. Friedman, H. Schwalb, H. Hallaq, A. Pinson and M. Heller, Biochim. biophys. Acta 598, 272 (1980).

12. H. Schwalb, Y. Dickstein and M. Heller, Biochim. biophys. Acta 689, 241 (1982).

13. W. Schoner, C. von Ilberg, R. Kramer and W. Seubert, Eur. J. Biochem. 1, 334 (1967).

14. O. H. Lowry, N. J. Rosebrough, A. L. Farr and R. J. Randall, J. biol. Chem. 193, 265 (1951).

15. K. Werdan, G. Bauriedel, M. Bozsik, W. Krawietz and E. Erdmann, Biochim. biophys. Acta 597, 364 (1980).

16. K. Werdan, G. Bauriedel, B. Fischer, W. Krawietz, E. Erdmann, W. Schmitz and H. Scholz, Biochim. biophys. Acta 687, 79 (1982).

17. B. Blondel, I. Roijen and J. P. Cheneval, Experientia 27, 356 (1971).

18. W. J. Marvin, R. B. Robinson and K. Hermsmeyer, Circulation Res. 45, 528 (1979).

19. T. B. Okarma, P. Tramell and S. M. Kalman, J. Pharmac. exp. Ther. 183, 559 (1972)

20. G. Scatchard, Ann. N.Y. Acad. Sci. 51, 660 (1949).

21. P. De Meyts and J. Roth, Biochem. biophys. Res. Commun. 66, 1118 (1975)

22. M. J. Weidemann, H. Erdelt and M. Klingenberg, Eur. J. Biochem. 16, 313 (1970).

23. E. Erdmann, in Handbook of Experimental Pharmacology Vol. 56/I, (Ed. K. Greeff), p. 337. Springer, Berlin (1981). 
24. K. Werdan, B. Wagenknecht, B. Zwissler, L. Brown, W. Krawietz and E. Erdmann, Biochem. Pharmac. 33, 55 (1984).

25. K. Werdan, B. Zwissler, B. Wagenknecht, W Krawietz and E. Erdmann, Biochem. Pharmac. 32, 757 (1983).

26. E. Erdmann and W. Schoner, Biochim. biophys. Acta 307, 386 (1973).

27. R. Kaufmann, H. Tritthart, S. Rodenroth and B. Rost, Pflügers Archs 311, 25 (1969)

28. O. F. Schanne and G. Bkaily, Can. J. Physiol. Pharmac. 59, 443 (1981).

29. S. Biedert, W. H. Barry and T. W. Smith, J. gen. Physiol. 74, 479 (1979).

30. B. Koidl and H. A. Tritthart, J. mol. cell. Cardiol. 12, 663 (1980).

31. M. Schwenk, T. Wiedmann and H. Remmer, NaunynSchmiedeberg's Archs Pharmac. 316, 340 (1981)

32. J. S. Cook, E. H. Tate and C. Shaffer, J. cell. Physiol. 110, 84 (1982).
33. J. F. Lamb and P. Ogden, Quart. J. exp. Physiol. 67, 105 (1982).

34. L. R. Pollack, E. H. Tate and J. S. Cook, Am. J. Physiol. 241, C173 (1981)

35. P. C. Will, J. W. Longworth, E. T. Brake and J. S. Cook, Molec. Pharmac. 13, 161 (1977).

36. T. Onji and M.-S. Liu, Archs Biochem. Biophys. 207 , 148 (1981).

37. L. Brown, K. Werdan and E. Erdmann, Biochem. Pharmac. 32, 423 (1983).

38. T. Godfraind and J. Ghysel-Burton, Proc. natn. Acad. Sci. U.S.A. 77, 3067 (1980).

39. T. Godfraind, J. Ghysel-Burton and A. DePover, Nature, Lond. 299, 824 (1982).

40. N. V. Wellsmith and G. E. Lindenmayer, Circulation Res. 47, 710 (1980).

41. A. DePover and T. Godfraind, Biochem. Pharmac. 28, 3051 (1979). 